Plano Básico Ambiental para Operação de Gasodutos: o caso do Gasoduto Bolívia Brasil

Ruy Alberto Campos Sarno

MONOGRAFIA

DEPARTAMENTO DE ENGENHARIA MECÂNICA

Programa de Pós-Graduação em Engenharia de Dutos

Rio de Janeiro

Maio de 2018

$\mathrm{CCe}$

COORDENAÇĀo

CENTRALDE

EXTENSÄO 


\title{
Plano Básico Ambiental para Operação de Gasodutos: o caso do Gasoduto Bolívia Brasil
}

\author{
Ruy Alberto Campos Sarno
}

Monografia apresentada ao Programa de PósGraduação Latu Sensu em Engenharia de Dutos da PUC-RJ como requisito final para obtenção do título de especialista em Engenharia de Dutos.

Orientador: Sidney Stuckenbruck

Central de Cursos de Extensão - PUC-Rio

Rio de Janeiro

Maio de 2018 


\section{Dedicatória}

A minha família pelo incentivo dado e o amor dedicado. 


\section{Agradecimentos}

A TBG pela oportunidade.

A PUC/CCE, em especial ao orientador e professor Sidney Stuckenbruck pela paciência e compreensão. 


\section{Resumo}

No mundo, a questão ambiental é cada vez mais relevante em relação à implantação de empreendimentos considerados de grande impacto ambiental, não sendo diferente no Brasil. O licenciamento ambiental realizado por órgãos governamentais é a ferramenta adequada e exigida para viabilizar ambientalmente esses empreendimentos, sempre embasado por estudos técnicos, de caráter ambiental.

No caso da indústria do gás natural, notadamente projetos de Gasodutos, o processo de licenciamento no Brasil desse tipo de empreendimento evoluiu nas últimas décadas, quer seja no aprimoramento de técnicas e/ou na evolução da gestão ambiental, trazendo resultados significativos para a indústria, a sociedade e para o meio ambiente.

Nessa monografia são discutidos:

- A questão ambiental, no mundo e no Brasil;

- O papel da indústria do gás natural, especificamente no transporte desse combustível por Gasodutos;

- O processo de licenciamento ambiental e o arcabouço legal relacionado a esse modal de transporte;

- Os estudos ambientais necessários ao processo de licenciamento, os quais subsidiam análises e decisões.

Também será apresentado, como estudo de caso, o licenciamento do Gasoduto Bolívia Brasil, considerando principalmente a recente demanda do órgão licenciador onde, de forma inédita, solicitou no âmbito da renovação da Licença de Operação desse empreendimento, a elaboração de um Projeto Básico Ambiental - PBA para a sua operação, contemplando programas ambientais específicos que sistematizam e refletem o processo de gestão ambiental.

Além disso, o trabalho em questão objetiva avaliar e discutir o processo de elaboração do PBA, verificando a sua condução dentro da TBG, dona do Gasoduto, a importância dada, o envolvimento e comprometimento das diversas áreas, bem como os resultados alcançados em termos de evolução da Gestão Ambiental até então praticada na companhia. 


\section{Palavras-Chave}

Dutos de transporte, Gás Natural, Licenciamento Ambiental, Estudos Ambientais. 


\section{Sumário}

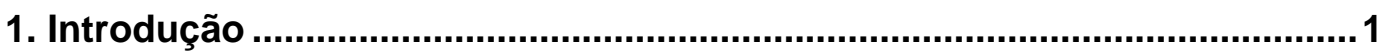

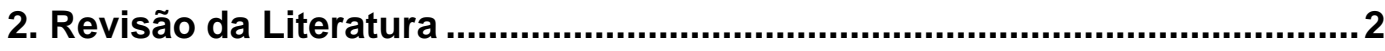

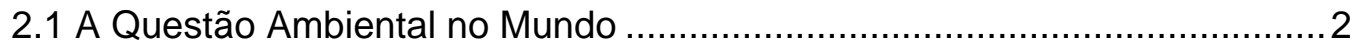

2.2 A Questão Ambiental no Brasil ............................................................. 4

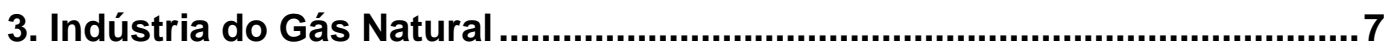

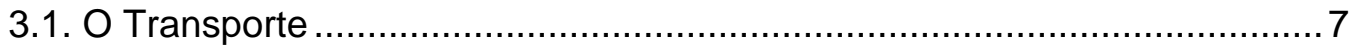

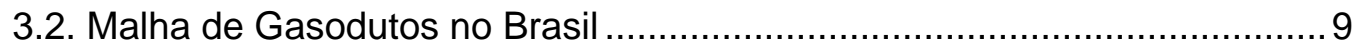

3.3. Licenciamento Ambiental de Gasodutos............................................ 13

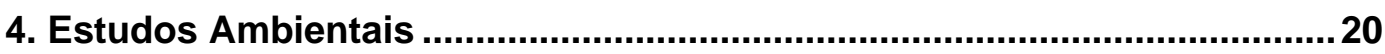

4.1. Avaliação de Impacto Ambiental - AIA .............................................. 21

4.2. Estudos Ambientais - EIA e o RIMA ….................................................... 25

4.3. O Plano ou Projeto Básico Ambiental - PBA...........................................22

5. Estudo de Caso: O PBA do Gasoduto Bolívia-Brasil ............................... 31

5.1. Características do Gasoduto Bolívia Brasil ......................................... 31

5.2. O traçado do Gasoduto Bolívia Brasil ................................................ 32

5.3. Operação e manutenção no Gasoduto Bolívia Brasil ............................... 38

5.4. Processo de licenciamento do Gasoduto Bolívia Brasil ...........................41 41

5.5. Programas Ambientais do PBA do Gasoduto Bolívia Brasil .................... 44

5.6. Atendimento às Condicionantes da L.O. 081/2000 - original ...................46 46

5.7. Atendimento das Condicionantes da LO 081/2000 - Renovada ................47

5.8.O PBA do Gasoduto Bolívia Brasil .......................................................49

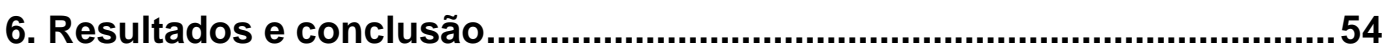

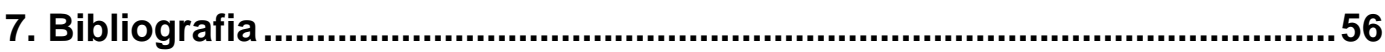




\section{Índice de Figuras}

Página

Figura 1: Malha de dutos no Brasil 11

Figura 2: Transporte de gás natural -2010/2016 11

Figura 3: Balanço de Gás Natural no Brasil - $\mathrm{m}^{3} /$ dia 13

$\begin{array}{ll}\text { Figura 4: Fases do Processo de Licenciamento } & 16\end{array}$

Figura 5: Empreendimento / Gasodutos Licenciados pelo IBAMA 28

Figura 6: Traçado do Gasoduto Bolívia Brasil - Atualmente 33

Figura 7: Traçado Original do Gasoduto Bolívia Brasil, apresentado no EIA 34

Figura 8: Logo da Linha do Gás da TBG 39

Figura 9: Marco delimitador, Marco Sinalizador e Placa de sinalização 40

Figura 10: Guia de convivência, distribuído ao longo da faixa de servidão 40

Figura 11: Impactos identificados no EIA original 50

Figura 12: Nova Matriz de Impacto Ambiental - 2014

Figura 13: Cronograma de atividades para elaborar o PBA 52

Figura 14: Acompanhamento das atividades de realização do PBA 53 


\section{Índice de Tabelas}

Página

Tabela 1: Gasodutos de Transporte no Brasil 10

Tabela 2: Definição de competências de licenciamento

Tabela 3: Tipos de Licenças do Processo de Licenciamento Ambiental 15

Tabela 4: Legislação Aplicável ao Licenciamento

Tabela 5: Principais Ferramentas de Avaliação de Impactos Utilizadas na AIA 23

Tabela 6: Lista de Gasodutos Licenciados pelo IBAMA 29

Tabela 7: Uso do Gás Natural Transportado pelo Gasoduto Bolívia Brasil

Tabela 8: Estados do Mato Grosso do Sul e São Paulo e respectivos Municípios atravessados pelo Gasoduto 35

Tabela 9 : Estados do Paraná, Santa Catarina e Rio Grande do Sul e respectivos Municípios atravessados pelo Gasoduto 35

Tabela 10: Relação de instalações fixas - PE 36

Tabela 11: Relação de instalações fixas - ECOMP 38

Tabela 12: Audiências Públicas Realizadas 42

Tabela 13: Estrutura do EIA Consolidado 43

Tabela 14: Programas Ambientais para as Obras 45

Tabela 15: Programas ambientais Compensatórios 46

Tabela 16: Condicionantes da LO 081/2000, Renovada - 2014 48

Tabela 17: Nova relação de Impactos ambientais - 2014 


\section{Nomenclatura}

AC

AIA

ANP

$\mathrm{AO}$

CETESB

CONAMA

DNER

DNPM

EPL

FUNAI

FUNASA

GASBOL

GASCAV

IBAMA

IPHAN

L.I.

L.O.

EIA

RIMA

FCP

EMED

ECOMP

L.P.

LAF

MMA

MME

NEPA

ONG

OPASA

TEBIG

REDUC

OSBRA

OPASC
Autorização de Construção

Avaliação de Impacto Ambiental

Agencia Nacional de Petróleo

Autorização de Operação

Companhia Ambiental do Estado de São Paulo

Conselho Nacional de Meio Ambiente

Departamento Nacional de Estradas de Rodagem

Departamento Nacional de Produção Mineral

Empresa de Planejamento e Logística

Fundação Nacional do Índio

Fundação Nacional da Saúde

Gasoduto Bolívia-Brasil

Gasoduto Cabiúnas - Vitória

Instituto Brasileiro de Meio Ambiente e dos Recursos Naturais

Renováveis

Instituto do Patrimônio Histórico e Artístico Nacional

Licença de Instalação

Licença de Operação

Estudo de Impacto Ambiental

Relatório de Impacto Ambiental

Fundação Cultural Palmares

Estação de Medição

Estação de Compressão

Licença Prévia

Licenciamento Ambiental Federal

Ministério de Meio Ambiente

Ministério de Minas e Energia

National Environmental Policy Act

Organização Não Governamental

Oleoduto REPLAN / Terminal de Barueri

Terminal da Ilha Grande

Refinaria Duque de Caxias

Oleoduto São Paulo-Brasília

Oleoduto REPAR - Terminal de Biguaçu 
ORSUB Oleoduto Recôncavo-Sul da Bahia

PBA Plano ou Projeto Básico Ambiental

PE Ponto de Entrega

PETROBRAS Petróleo Brasileiro S.A.

PNMA Política Nacional do Meio Ambiente

RFFSA Rede Ferroviária Federal

SCADA Sistema de Controle Supervisório e de Aquisição de Dados

SISNAMA Sistema Nacional do Meio Ambiente

SMS Saúde, Meio Ambiente e Segurança

TBG Transportadora Brasileira do Gasoduto Bolívia/Brasil S.A.

TEBAR Terminal de São Sebastião

OSPLAN Oleoduto Terminal de Guararema - REPLAN

TRANSPETRO Petrobras Transporte S.A.

ECO/92 Sigla da Conferência das Nações Unidas sobre o Meio Ambiente e o Desenvolvimento 


\section{Introdução}

O Licenciamento Ambiental de dutos, especificamente de Gasodutos, tem sido fundamental para liberação da implantação e operação desse tipo de empreendimento. Tal procedimento, de ordem administrativa e legal, demanda estudos específicos, avaliações críticas, a proposição de programas para gerenciamento ambiental e a implementação efetiva de medidas mitigadoras dos impactos ambientais identificados, e avaliados, durante as obras e na própria operação.

Esse trabalho visa apresentar aspectos da questão ambiental, no mundo e no Brasil, uma visão da indústria do gás natural e o seu processo de licenciamento ambiental, além de trazer como estudo de caso o licenciamento do Gasoduto Bolívia Brasil, um dos maiores gasoduto do país, discutindo aspectos da gestão ambiental desse projeto e a demanda do órgão licenciador que estabeleceu, de forma inédita, na renovação da Licença de Operação desse empreendimento, a elaboração de um Projeto Básico Ambiental - PBA para a sua operação.

Assim, é avaliada e discutida a evolução do processo de gestão ambiental implementado no Gasoduto Bolívia-Brasil contrapondo com a elaboração do Projeto Básico Ambiental - PBA.

Nesse sentido, de forma detalhada será apresentado o processo de planejamento e mobilização para atendimento ao órgão ambiental licenciador, principalmente para elaboração do PBA considerando o histórico da operação na época, cerca de 15 anos, além de rever as medidas praticadas até então na gestão ambiental.

Ao final, serão apresentadas as conclusões acerca do tema, como os resultados obtidos no processo de elaboração do Projeto Básico Ambiental PBA para a operação do Gasoduto Bolívia Brasil. 


\section{Revisão da Literatura}

\subsection{A Questão Ambiental no Mundo}

O meio ambiente faz parte do contexto da vida humana, não sendo possível separá-lo desse processo. Considerando as atividades dos seres humanos, com foco no desenvolvimento socioeconômico, e o antagonismo em relação às questões que envolvem o meio ambiente, nem sempre foi fácil atingir um ponto de equilíbrio adequado que atendesse aos interesses de todos. A poluição e os impactos ambientais do desenvolvimento sempre visíveis e os benefícios proporcionados pelo progresso justificados como sendo necessários.

Destaca-se que o termo "meio ambiente" foi usado pela primeira vez numa importante reunião denominada reunião do Clube de Roma (realizada em 1968 em Roma, Itália), onde a as discussões sobre as questões ambientais e desenvolvimento passaram a ter relevância (SOUZA, 2009).

Segundo Souza (2009), o Clube de Roma era composto por representantes da sociedade organizada (cientistas, industriais e políticos), objetivando discutir e analisar os limites do crescimento econômico versus o uso constante e crescente dos recursos naturais. Diagnosticaram que os problemas estavam relacionados diretamente à industrialização acelerada, rápido crescimento demográfico, escassez de alimentos, esgotamento de recursos não renováveis, deterioração do meio ambiente. ${ }^{1}$

Nessa reunião, definiu-se o meio ambiente da seguinte forma: "O meio ambiente é o conjunto de componentes físicos, químicos, biológicos e sociais capazes de causar efeitos diretos ou indiretos, em um prazo curto ou longo, sobre os seres vivos e as atividades humanas." No caso do Brasil, considerando a Política Nacional do Meio Ambiente (PNMA) brasileira, estabelecida pela Lei 6938 de 1981, meio ambiente foi definido como: "o conjunto de condições, leis, influências e interações de ordem física, química e biológica, que permite, abriga e rege a vida em todas as suas formas" (SOUZA, 2009).

\footnotetext{
${ }^{1} \mathrm{O}$ documento mais relevante produzido e com grande repercussão entre os cientistas e os governantes foi o Relatório Meadows, também conhecido como Relatório do Clube de Roma.
} 
Logo em seguida, em 1969, deu-se a primeira manifestação institucionalizada de política sobre impactos ao meio ambiente, com a criação do NEPA (National Environmental Policy Act) nos Estados Unidos da América, sendo definido importante instrumento de Política Ambiental denominado de Avaliação de Impacto Ambiental - AIA (SÁNCHEZ, 2015).

Segundo Sánchez (2015), esse instrumento da política ambiental norteamericana, definiu para empreendimentos de potencial impacto ambiental, a identificação dos mesmos, considerando os efeitos ambientais negativos da proposta, alternativas da ação, relação dos recursos ambientais negativos no curto prazo e a manutenção ou mesmo melhoria do seu padrão no longo prazo e, por fim, a definição clara quanto a possíveis comprometimentos dos recursos ambientais para o caso de implantação da proposta.

A AIA, pela sua importância, também foi adotado pela França, Canadá, Holanda, Grã-Bretanha e Alemanha. No Brasil, a AIA foi formalmente introduzida no Brasil pela Política Nacional de Meio Ambiente, instituída na Lei n 6938/81 (SÁNCHEZ, 2015).

Com a crescente tomada de consciência ambiental, a emergência de novos temas, o fortalecimento das políticas ambientais e a pressão sobre governantes, importantes forças se destacaram por intensificar e buscar transformar discussões em resoluções de problemas, no caso a academia; as organizações não governamentais e setores governamentais (SÁNCHEZ, 2015).

Tal fato elevou a consciência e o nível dos debates, culminando na realização de importantes eventos como a Conferência Mundial de Meio Ambiente, realizada em 1972 em Estocolmo; a produção do Relatório Brundtland (Nosso Futuro Comum) e a Conferência das Nações Unidas sobre Meio Ambiente e Desenvolvimento (Conhecida como ECO / 92), realizada em 1992 na cidade do Rio de Janeiro (SOUZA, 2009)

A Conferência Mundial de Meio Ambiente, ainda segundo Souza (2009) objetivou "estabelecer uma visão global e princípios comuns, que sirvam de inspiração e orientação à humanidade para preservação e melhoria do ambiente". Estabeleceu a Declaração sobre o Ambiente Humano, que define: "...deve ser confiada, às instituições nacionais competentes, a tarefa de planificar, administrar e controlar a utilização dos recursos naturais dos Estados, com o fim de melhorar a qualidade do meio ambiente".

Já o Relatório Brundtland (Brundtland, 1987), foi produzido pela Comissão Mundial Sobre Meio Ambiente, conduzido na época pela Primeira Ministra Norueguesa, Sra. Gro Harlem Bruntdland. Apresenta uma visão 
complexa das causas dos problemas socioeconômicos e ecológicos, e suas inter-relações com a economia, tecnologia, sociedade civil e política. Propõe e discute a aplicação do Desenvolvimento Sustentável que é: "aquele que satisfaz as necessidades de gerações presente sem comprometer a possibilidade das gerações futuras atenderem as suas próprias necessidades".

A ECO/92 foi realizada e meio a forte pressão internacional visando a preservação ambiental e repreensão aos países de terceiro mundo. Aconteceu nesse evento ampla discussão em todos os níveis da sociedade organizada governos, organizações não governamentais, empresários, academias e meio cientifico. Foram resultados desse evento: Declaração do Rio sobre Meio Ambiente e desenvolvimento; Agenda 21 - ações para o desenvolvimento sustentável; Declaração de princípios sobre Florestas Mudanças Climáticas e Convenção sobre Biodiversidade (SOUZA, 2009).

Nesse ponto, com todos os debates, a atuação do Estado se tornou essencial para definir limites e estabelecer normas, na forma de leis, para preservar o bem comum, o meio ambiente (OLIVEIRA, 2012). E o processo adotado para avaliar a implantação e operação de empreendimentos, seus aspectos e impactos ambientais visando, sobretudo, a mitigação de tais impactos, foi processo de licenciamento ambiental, definido em leis. Tal processo utiliza como base para tomada de decisão, os resultados de estudos ambientais específicos, todos considerados no então instrumento de Política Ambiental adotado em boa parte do mundo, no caso a Avaliação de Impacto Ambiental - AIA.

\subsection{A Questão Ambiental no Brasil}

\subsubsection{Marco Legal}

O avanço do tratamento das questões ambientais, a partir das discussões e aumento do nível de conscientização da sociedade organizada, refletiu diretamente no aprimoramento da legislação ambiental (OLIVEIRA, 2012).

Ainda segundo Oliveira (2012), no Brasil, em nível Federal, houve a promulgação da Lei 6.803 , de 1980 , sendo a primeira a tratar a questão ambiental, notadamente o licenciamento, estabelecendo inclusive diretrizes para zoneamento ambiental.

Em 1981 foi definida a Política Nacional de Meio Ambiente (PNMA - Lei 6.938), regulamentada pelo Decreto Federal 99.274/90. Tal lei reflete a preocupação do governo brasileiro em relação à proteção ambiental no país. A 
PNMA tem importância significativa, como marco zero da consciência ambiental brasileira, considerando que sua promulgação define conceitos relacionados ao meio ambiente (desenvolvimento sustentável, equilíbrio ecológico, dentre outros) e passaram a fazer parte do vocabulário jurídico, tendo como consequência o desenvolvimento do Direito Ambiental (GODOY, 2005).

Sete anos depois, em 1988, é promulgada a Constituição Federal, que buscou estabelecer o balanceamento entre o direito ao meio ambiente equilibrado, o desenvolvimento econômico e social sustentável, laçando assim a base do desenvolvimento sustentável, conforme Artigo 225 que diz: "todos têm direito ao meio ambiente ecologicamente equilibrado, bem de uso comum do povo e essencial à sadia qualidade de vida, impondo-se ao Poder Público e à coletividade o dever de defendê-lo e preservá-lo para as presentes e futuras gerações." Assim, o meio ambiente passou a ser direito fundamental do cidadão, cabendo ao governo e ao cidadão resguardá-lo (GODOY, 2005).

Até então, a defesa do meio ambiente é importante princípio norteador das atividades econômicas, conforme a Constituição Federal de 1988, não sendo aceitável qualquer atividade, seja da iniciativa privada ou pública, que pudesse provocar impactos ambientais e, consequentemente, não atendesse a legislação ambiental pertinente (OLIVEIRA, 2012).

Por outro lado, o licenciamento ambiental, enquanto instrumento principal da Política Ambiental Brasileira primou pelo desenvolvimento sustentável, objetivando o equilíbrio entre o ser humano e as questões ambientais. Importância fundamental é dada à compatibilidade do desenvolvimento econômico com o meio ambiente, respeitando-se sempre a capacidade de regeneração e permanência dos ecossistemas ambientais (preservação ambiental) (OLIVEIRA, 2012).

Assim, foi criado em 1989 o órgão ambiental federal pela Lei Federal 7.735/89, denominado Instituto Brasileiro de Meio Ambiente e dos Recursos Naturais Renováveis (IBAMA), com o objetivo de integrar a gestão ambiental no Brasil. Tem a função de licenciar, realizar controle da qualidade ambiental, autorizar o uso de recursos naturais, além de realizar fiscalização, monitoramentos e controle em todo território nacional.

Nesse sentido, houve necessidade de organizar o Estado. A partir da PNMA foi instituído o Sistema Nacional do Meio Ambiente - SISNAMA (Decreto Federal 99.274/1990), constituído pelos órgãos e entidades da União, dos Estados, do Distrito Federal, dos Municípios e pelas fundações instituídas pelo poder público, sendo responsável pela proteção e melhoria da qualidade 
ambiental. O órgão consultivo e deliberativo do SISNAMA é o Conselho Nacional de Meio Ambiente (CONAMA), responsável, dentre outras atribuições, pela elaboração de normas e critérios para licenciamento e manutenção da qualidade ambiental (CARMO E SILVA, 2013).

Já as definições, responsabilidades, critérios básicos e diretrizes gerais, visando a utilização da Avaliação de Impactos Ambientais (AIA), foram definidas a partir da Resolução CONAMA 001/1986. Destaca-se que essa Resolução instituiu a aplicação da AIA como instrumento licenciamento ambiental, sendo requerida basicamente para alguns tipos de empreendimento/ atividade, mas sem exigir a definição de planos, programas e políticas (CARMO E SILVA, 2013).

Ainda segundo os autores Carmo e Silva (2013), o licenciamento ambiental abrangeu uma gama significativa de empreendimentos, desde infraestrutura (incluindo empreendimentos dutoviários), indústrias extrativas, projetos de expansão urbana, agropecuária, indústrias de transformação e turismo, considerando, sobretudo, os seus potenciais de causar impactos e, consequentemente, degradação ambiental. O licenciamento obrigatório para esses empreendimentos primou em definir mecanismos de controle ambiental visando garantir a qualidade ambiental.

Mas, somente em dezembro de 1997 o CONAMA elaborou e promulgou o que veio a ser a Resolução mais importante, a Resolução CONAMA 237/1997, que definiu e estabeleceu, de forma clara, o processo de licenciamento ambiental no Brasil, dada a necessidade efetiva de se ter um instrumento de gestão ambiental apropriado, instituído pela PNMA (SOUZA, 2009).

Nesse sentido, o licenciamento de empreendimentos de significativo impacto ambiental passou a seguir rigorosamente as diretrizes da CONAMA 237/1997, com destaque para a indústria de gás natural, notadamente os gasodutos de transporte, num processo evolutivo de gestão ambiental, conforme discorrido nos próximos itens dessa monografia. 


\section{Indústria do Gás Natural}

\subsection{O Transporte}

A opção de transporte dutoviário, na atividade de combustíveis e considerando o transporte de óleo, gás, biocombustíveis e derivados, vem demonstrando ser vantajosa, do ponto de vista econômico, e confiável, do ponto de vista de segurança (FREIRE et. al, 2009). Podem ser destacadas, segundo os autores, as seguintes vantagens:

- Alta confiabilidade (operação contínua, automação e segurança de processo e ambiental)

- Economia no transporte (maior quantidade transportada a baixo custo, se comparado aos demais modais)

- Baixo consumo de energia (consumo de energia versus distancia de transporte, se comparado aos demais modais);

- Baixo impacto ambiental (em relação à poluição do ar, ruído e acidentes, se comparado aos demais modais).

Segundo os autores, o modal dutoviário, no século $X X$, cresceu significativamente no mundo considerando a evolução tecnológica e uso intensivo de combustíveis. No Brasil não foi diferente, tendo sido tal atividade iniciada em 1948, a partir do Conselho Nacional de Petróleo, desenvolvendo-se de forma estruturada a partir da criação da PETROBRAS, em 1953, a partir da Lei $2004 / 53 .^{2}$

A seguir, apresenta-se os principais marcos históricos dessa atividade, segundo Caldas (2006):

- Ano de 1966. Funcionamento do Oleoduto Rio/Belo Horizonte, transporte da Refinaria Duque de Caxias para Belo Horizonte, com 365 km de extensão (primeiro duto de grande extensão no Brasil);

- Década de 70. Construção de terminais e dutos: ampliação do Terminal de São Sebastião (TEBAR) e construção dos oleodutos: OSPLAN, OPASA e o

\footnotetext{
2 A lei 2004/53, dispõe sobre a Política Nacional do Petróleo, estabelecendo como monopólio da União a pesquisa, lavra, refino e transporte do petróleo, além de criar a Petróleo Brasileiro S.A. (PETROBRAS).
} 
Guararema/São José dos Campos além do Terminal da Ilha Grande (TEBIG) e o oleoduto Angra dos Reis/Caxias.

- Ano de 1973. Produção regular da plataforma continental, nos campos de Guaricema e Caioba, no litoral de Sergipe, através de um oleoduto submarino de 16" para o Terminal de Atalaia.

- Entre os anos de 1977 e 1979. Operação 3 minerodutos no país: Ilha de Mangaratiba (BA) -Vera Cruz (BA), Mariana (MG) - Ponta de Ubu (ES), e Tapira (MG) -Uberaba (MG);

- Década de 80. Construção de gasodutos Lagoa Parda-Vitória, Praia do Furado/Cabiúnas e Cabiúnas/REDUC.

- Década de 90. Destaque para a construção de polidutos, como o OSBRA, OPASC e ORSUB.

- Ano de 2000. Conclusão do primeiro gasoduto internacional, Gasoduto Bolívia- Brasil, com 3.593 km de extensão (início no Rio Grande, na Bolívia, e término em Canoas, na Grande Porto Alegre). Gasoduto operado pela Transportadora Brasileira do Gasoduto Bolívia/Brasil S.A. (TBG).

No processo de evolução do setor, foi revogada a Lei 2004/53 e promulgada, em agosto de 1997, a Lei Federal 9.478/97 (Lei do Petróleo), definindo, dentro de outros aspectos, a livre concorrência; ampliação da competitividade e do mercado; ampliação e garantia de fornecimento de combustível; proteção ao consumidor e ao meio ambiente; desenvolvimento tecnológico e o uso de novos combustíveis.

Cumprindo ao determinado no Artigo 65 da referida lei, foi criada a Petrobras Transporte S.A. - TRANSPETRO, em 1998, subsidiária da Petrobras com a finalidade de "atuar no transporte e armazenagem de granéis, petróleo e seus derivados e de gás natural, por meio de dutos e navios, e na operação de terminais.

Os dutos de transferência, segunda a mesma lei, ficaram sob responsabilidade da PETROBRAS, que passou a ter participação nas empresas de transporte de gás natural, incluindo a Transportadora Brasileira Gasoduto Bolívia-Brasil, Transportadora Sulbrasileira de Gás, Transportadora Norte Brasileira de Gás, Transportadora Amazonense de Gás, Transportadora Capixaba de Gás e Transportadora Nordeste-Sudeste (CALDAS, 2006).

Segundo Caldas (2006), a evolução tecnológica, garantindo a confiabilidade e integridade estrutural do duto, além da demanda crescente de petróleo, gás e derivados no país, tem sido determinante para adoção do transporte dutoviário, sem falar nas vantagens descritas anteriormente. 
Não obstante os avanços promovidos pela Lei do Petróleo, em 2009 foi promulgada a Lei 11.909/09, conhecida como a Lei do Gás, após debate entre representantes do Congresso, Governo e indústria do gás por quase quatro anos. $^{3}$ Tal lei buscou complementar as lacunas deixadas pela Lei do Petróleo, criando uma estrutura institucional para a indústria do gás natural no país. Tal Lei busca estimular a competição no mercado de gás e consequente atração de investimentos para as atividades de exploração e produção, ampliação da infraestrutura de transporte e regras para acesso de terceiros à malha (PINTO, 2014).

\subsection{Malha de Gasodutos no Brasil}

De acordo com a Agencia Nacional de Petróleo (ANP, 2017), até 2016 a malha de gasodutos de transporte correspondia a 9,4 mil quilômetros em operação (47 gasodutos), sendo $252 \mathrm{~km}$ em projeto, conforme tabela 1 abaixo.

\footnotetext{
${ }^{3}$ A discussão sobre a indústria do gás resultou na Lei 11.909/09, tendo como base três importantes projetos apresentados no Congresso Nacional: PL226/2005; PL 6666/2006 e PL 6676/2006.
} 
Tabela 1: Gasodutos de Transporte no Brasil

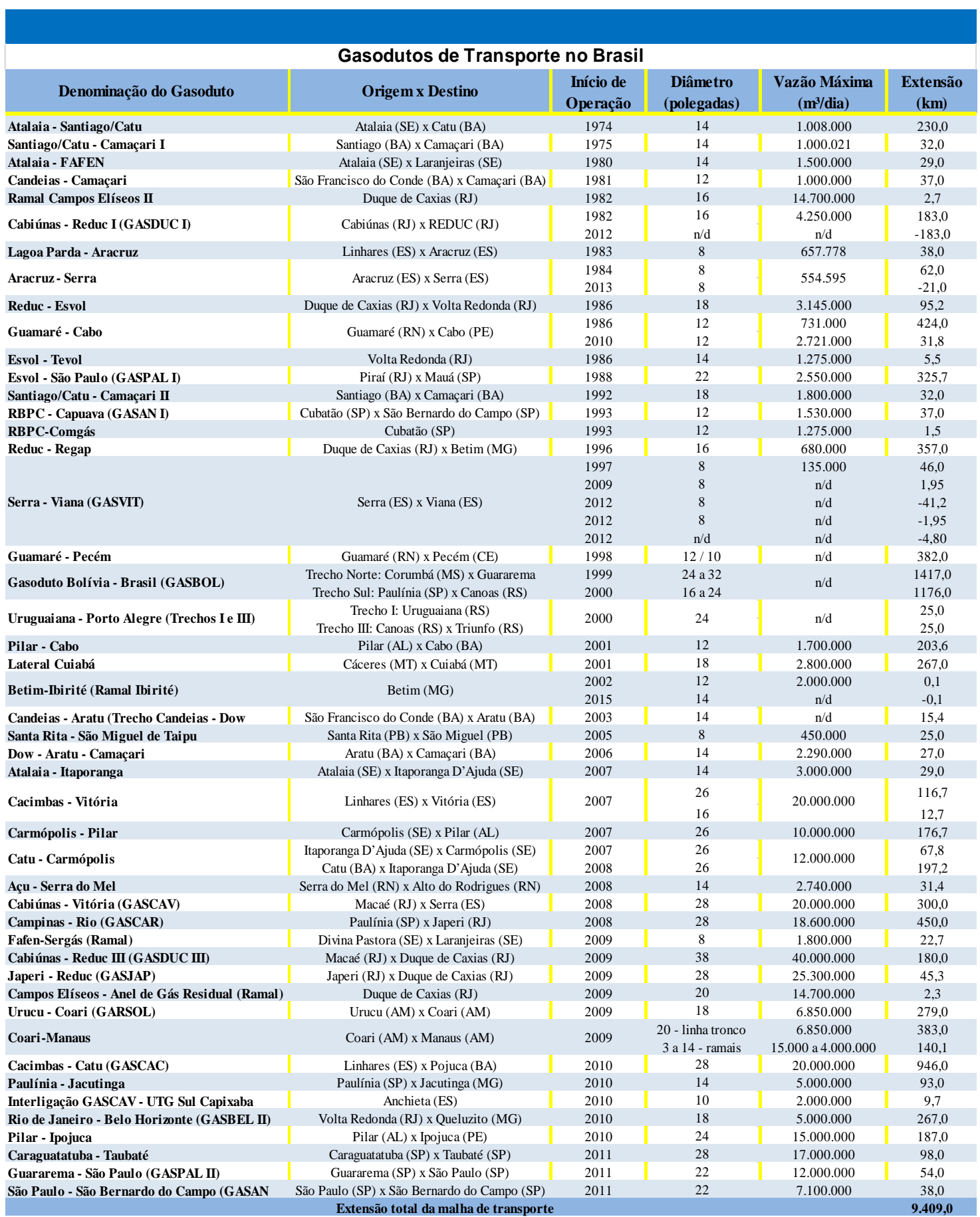

Fonte: ANP (2018) 
A malha de gasodutos de transporte até 2016, segundo ainda a ANP, teria a seguinte configuração:

Figura 1: Malha de dutos no Brasil

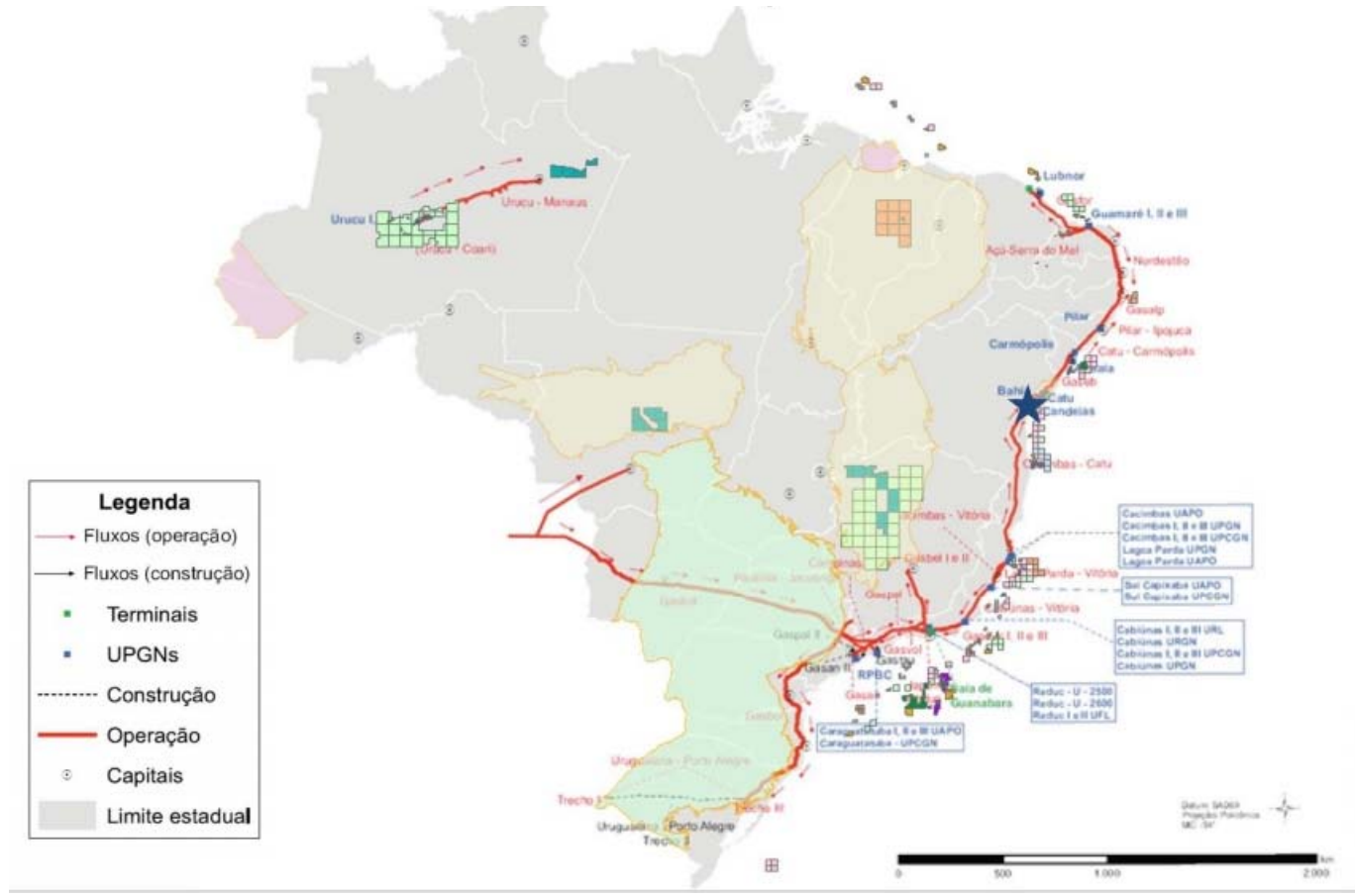

Fonte: ANP (2018)

Tal malha, segundo o Anuário Estatístico de Transportes (EPL, 2018), vem evoluindo e transportando volumes significativos de gás. Considerando o período de 2010 a 2015, com aumento de $30 \%$ nesse intervalo, observando-se o pico de 99,3 milhões de metros cúbicos/dia, em 2014 (cerca de 61\% de aumento em relação a 2010), com pequeno decréscimo de 19 \% em 2016, conforme pode ser observado na figura abaixo:

Figura 2: Transporte de gás natural -2010/2016

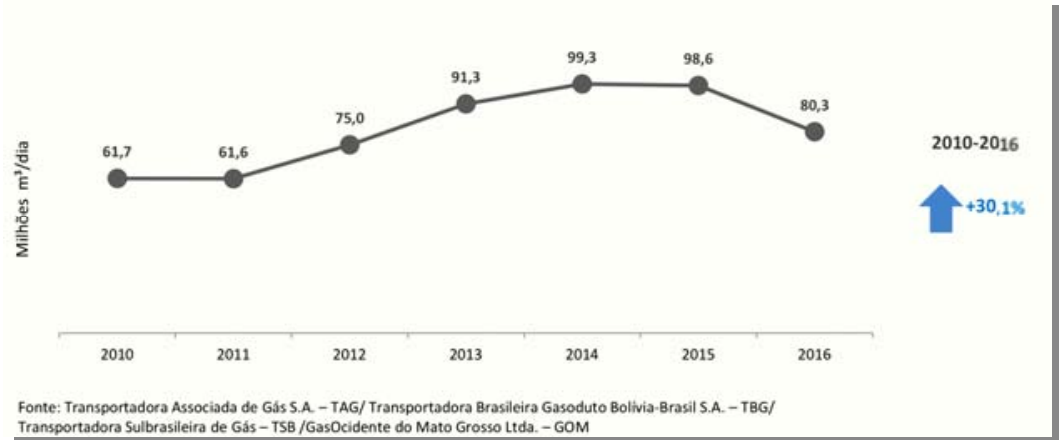

Fonte: EPL (2018) 
Além disso, algumas iniciativas têm sido discutidas e implementadas com o objetivo de desenvolver o setor de gás natural, a exemplo do aprimoramento do marco legal e regulatório com o programa Gás para Crescer (MME, 2016) que visa basicamente discutir:

1. Comercialização do gás natural

2. Tarifação por entrada e saída;

3. Compartilhamento de infraestrutura;

4. Harmonização das regulações Estaduais e Federais;

5. Incentivo à demanda;

6. Harmonização dos setores elétrico e de gás natural;

7. Gestão independente do transporte e instalações de estocagem;

8. Definição da política de comercialização;

9. Tributação

10. Apoio às negociações de contratos de gás e outras alternativas.

As novas diretrizes para o crescimento da indústria de gás natural deverão atrair investimentos, notadamente no seu transporte, ampliando a malha existente. Ressalta-se a tendência de aumento da produção nacional, com destaque para consumo industrial e geração elétrica, conforme figura abaixo:

Figura 3: Balanço de Gás Natural no Brasil - $\mathrm{m}^{3} / \mathrm{dia}$

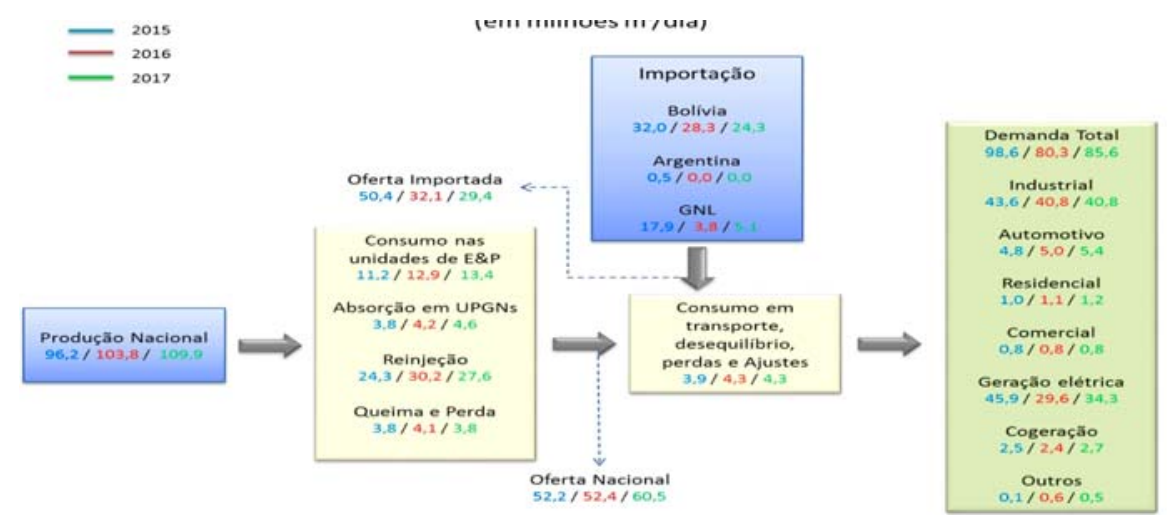

Fonte: MME,(2018) 


\subsection{Licenciamento Ambiental de Gasodutos}

O licenciamento ambiental é um dos processos fundamentais para viabilização ambiental de qualquer empreendimento de duto, em especial gasodutos pela necessidade de se realizar estudos de Análise de Risco visando a prevenção de grandes acidentes, evitando-se danos ao patrimônio das empresas, mas principalmente aos ecossistemas e às comunidades do entorno (CORTELETTI, 2009).

São várias as definições de risco. Nos Estados Unidos da America, a Agencia de Proteção Ambiental (EPA) definiu, em 1998, como sendo "Medida de perda econômica e/ou danos à vida humana (fatalidades) resultante da combinação da frequência de ocorrência do evento e a magnitude das perdas ou danos (consequência) ". No brasil, a CETESB, órgão Estadual Paulista, também em 1998, define risco como sendo a combinação entre a frequência de ocorrência de um acidente e a sua consequência (COETELETTI, 2009).

Em termos conceituais, o processo de licenciamento ambiental de gasodutos, a despeito de demais empreendimentos, segue basicamente a Resolução CONAMA 237/97, que normatiza o processo, definindo-o como:

\footnotetext{
"Um procedimento administrativo pelo qual o órgão ambiental competente licencia a localização, instalação, ampliação e a operação de empreendimentos e atividades utilizadores de recursos ambientais considerados efetiva ou potencialmente poluidores ou daqueles que, sob qualquer forma, possam causar degradação ambiental, considerando as disposições legais e regulamentares e as normas técnicas aplicáveis ao caso (BRASIL, 1997 - CONAMA 237/97) ".
}

Importante destacar que o licenciamento ambiental é de responsabilidade do Poder Executivo, que desempenha importante papel no processo de busca do equilíbrio entre as atividades socioeconômicas e o meio ambiente objetivando sobretudo, o desenvolvimento econômico necessário, e esperado, associado à preservação e conservação ambiental.

A CONAMA 237/1997 define competências e responsabilidades da União, Estado e Municípios, conforme apresentado a seguir na tabela 2. 
Tabela 2: Definição de competências de licenciamento

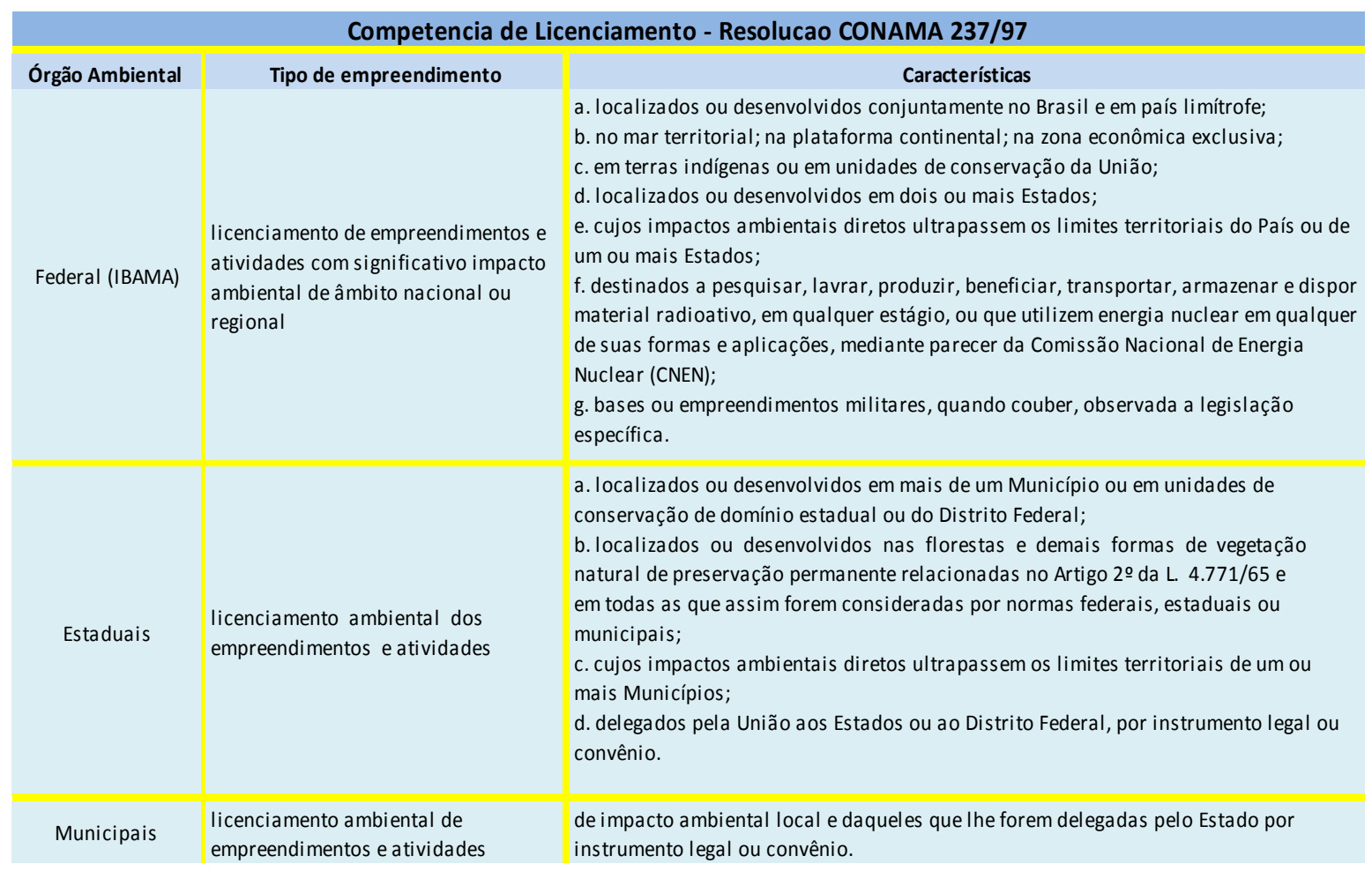

Fonte: Brasil (1997 - CONAMA 237/97)

Vale destacar algumas situações e condições específicas para o licenciamento, estabelecidas pela CONAMA 237:

- Em determinadas situações, por meio de Convenio, IBAMA poderá delegar aos Estados o licenciamento de atividades com significativo impacto ambiental;

- Empreendimentos e atividades são licenciados em um único nível de competência;

- Deverão ser emitidos Termos de Referências para elaboração de estudos que subsidiarão as análises do órgão ambiental, notadamente para concessão da LP.

- Além de atendimento às condicionantes da LP, para a LI será necessário o desenvolvimento do Plano Básico Ambiental (PBA) contendo Planos e Programas para garantir a Gestão Ambiental das obras de implantação.

- Dutos, estradas, linhas de transmissão, todos de grandes extensões (empreendimentos lineares), são normalmente licenciamentos realizados pelo IBAMA.

De acordo com o Decreto Federal 99.274/90 e a CONAMA 237/97, serão expedidas pelo órgão ambiental três tipos de licenças ambientais: Licença Prévia (LP), Licença de Instalação (LI) e Licença de Operação (LO), conforme descrito na tabela 3 abaixo: 
Tabela 3: Tipos de Licenças do Processo de Licenciamento Ambiental

\begin{tabular}{|c|c|c|c|c|c|}
\hline \multicolumn{6}{|c|}{ Tipos de Licenças Ambientais Concedidas } \\
\hline Licença & Fase Emissão & Condições & Caracteristica & Definições & Validade \\
\hline Licença Prévia (LP) & $\begin{array}{l}\text { Planejamento e concepção } \\
\text { do Empreendimento }\end{array}$ & $\begin{array}{l}\text { Apresentação de Estudos Ambientais } \\
\text { e realizção de Audiências Públicas }\end{array}$ & $\begin{array}{l}\text { Quando concedida, } \\
\text { atesta a localização do } \\
\text { empreendimento e sua } \\
\text { viabilidade ambiental. }\end{array}$ & $\begin{array}{l}\text { Estabelece } \\
\text { condicionantes para } \\
\text { desenvolvimento do } \\
\text { projeto executivo }\end{array}$ & $\begin{array}{c}\text { No minimo } 05 \\
\text { anos }\end{array}$ \\
\hline Licença de Instalação (니) & $\begin{array}{l}\text { Projeto Executivo e } \\
\text { expecificações de medidas } \\
\text { de controle ambiental. }\end{array}$ & $\begin{array}{l}\text { Atendimento às condicionantes da } \\
\text { LP. Podem ocorrer estudos } \\
\text { complementares }\end{array}$ & $\begin{array}{l}\text { Quando concedida, } \\
\text { autoriza as obras de } \\
\text { instalação do } \\
\text { Empreendimento. }\end{array}$ & $\begin{array}{l}\text { Estabelece } \\
\text { condicionantes para } \\
\text { atendimento durante as } \\
\text { obras de implantação } \\
\text { do empreendimento. }\end{array}$ & $\begin{array}{c}\text { No máximo } 06 \\
\text { anos }\end{array}$ \\
\hline Licença de Operação (LO) & $\begin{array}{l}\text { Solicitada com as obras } \\
\text { concluídas e pouco antes } \\
\text { da operação }\end{array}$ & $\begin{array}{l}\text { Atendimento às condicionantes da } \\
\text { LP/LI e demanda vistoria prévia pelo } \\
\text { órgão a mbiental }\end{array}$ & $\begin{array}{l}\text { Quando concedida, } \\
\text { autoriza a operação do } \\
\text { Empreendimento. }\end{array}$ & $\begin{array}{c}\text { Estabelece } \\
\text { condicionantes para } \\
\text { atendimento durante as } \\
\text { operação do } \\
\text { empreendimento. }\end{array}$ & $\begin{array}{l}\text { No mínimo } 04 \\
\text { e máximo de } \\
10 \text { anos }\end{array}$ \\
\hline
\end{tabular}

Fonte: Brasil (1997 - CONAMA 237/97)

São definidas ainda para as licenças e o processo de licenciamento ambiental algumas condições:

- Licenças poderão ser expedidas isoladas ou sucessivamente, de acordo com a natureza, características e fase do empreendimento ou atividade;

- No processo de licenciamento poderão ser consultados órgãos ambientais Estaduais e Municipais, como outros órgãos públicos e autarquias;

- A renovação da L.O. deve ser requerida com antecedência mínima de 120 dias antes da expiração do prazo de validade;

- Cada fase do licenciamento deverá ser dada a devida publicidade, a partir de publicações em Diário Oficial e Jornais de grande circulação;

- Os prazos de análise do órgão ambiental são diferenciados devido às características de cada licença, sendo o prazo máximo de 06 meses até o deferimento ou indeferimento. No caso da concessão da L.P., quando há estudos ambientais e audiência pública, o prazo poderá ser até um ano;

- Poderá haver alterações/prorrogações de prazos desde que devidamente justificado pelo empreendedor e concordância do órgão ambiental;

- As condicionantes de licença são divididas em dois grupos: Gerais (exigências relacionadas ao atendimento legal no tocante ao licenciamento ambiental) e Específicas (restrições e exigências técnicas associadas ao empreendimento);

Considerando as etapas para obtenção de cada licença definidas na Resolução CONAMA 237, considerando o planejamento de implantação de empreendimentos, apresenta-se a seguir figura simplificada para obtenção da L.P., L.I. e L.O.: 
Figura 4: Fases do Processo de Licenciamento

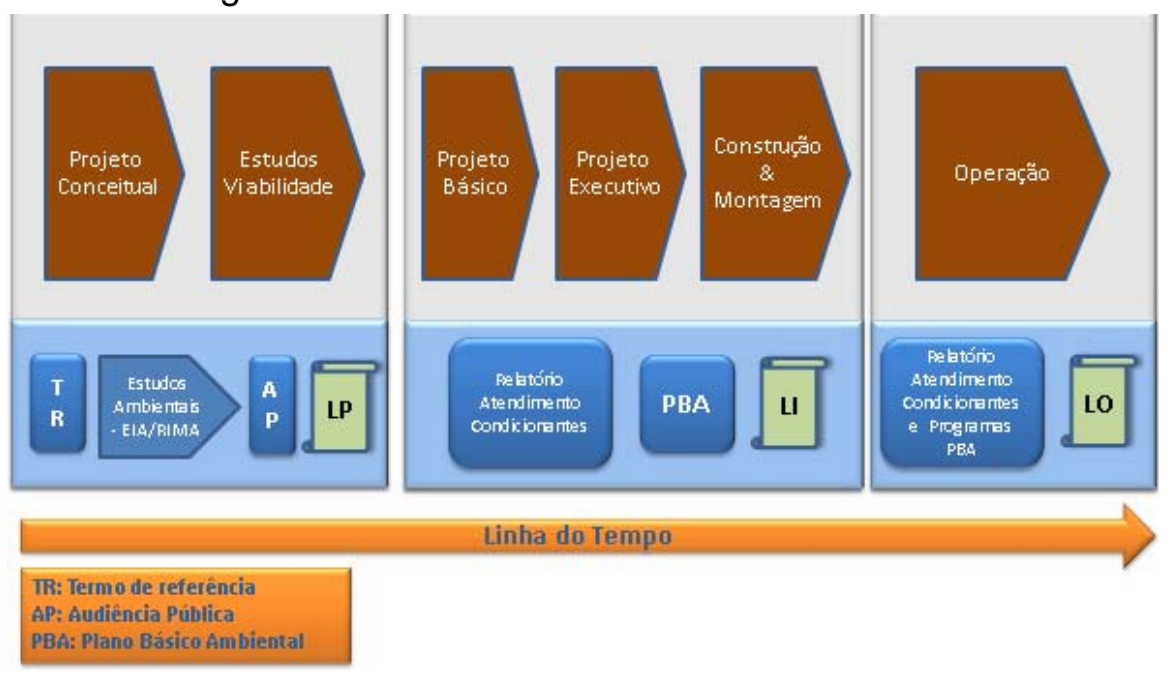

Fonte: Modificado de Brasil, 1997 - Conama 237

Conforme Figura 4, a Licença Prévia (L.P.) é solicitada na fase inicial do empreendimento e visa garantir a Viabilidade Ambiental do mesmo. Discute a localização e a concepção tecnológica, definindo condições para serem atendidas no Projeto Básico e no Executivo. A Licença de Instalação (LI), como o próprio nome diz, autoriza as obras após atendimento de todas as condicionantes estabelecidas na L.P. e aprovação, pelo órgão ambiental, do Plano Básico Ambiental (PBA), que é o conjunto de Programas Ambientais para mitigar impactos e definir a gestão ambiental nas obras.

Por fim, a Licença de Operação (L.O.) autoriza a operação do empreendimento, desde que comprovado 0 atendimento a todas as condicionantes estabelecidas na L.P. e na L.I.

Além da CONAMA 237, que estabelece situações e condições especificas para licenciamento, no âmbito federal, outras legislações devem ser observadas e, se aplicável, atendidas, conforme tabela resumo apresentado a seguir: 
Tabela 4: Legislação Aplicável ao Licenciamento

\begin{tabular}{|c|c|c|c|}
\hline \multicolumn{4}{|c|}{ Principais Leis, Decretos, Resoluções e Instruções consideradas no Licenciamento (Federal) } \\
\hline TIPO & № & ANO & ASSUNTO \\
\hline Constituição Federal & & 1988 & Direito fundamental ao meio ambiente \\
\hline Lei Complementar & 140 & 2011 & Proteção ao Meio Ambiente \\
\hline Decreto Lei & $\begin{array}{l}24.643 \\
25 \\
227 \\
1.413\end{array}$ & $\begin{array}{l}1943 \\
1937 \\
1967 \\
1975\end{array}$ & $\begin{array}{l}\text { Código de Águas } \\
\text { Patrimônio Arqueológico } \\
\text { Código de Mineração } \\
\text { Controle de Poluição }\end{array}$ \\
\hline Leis ordinárias & $\begin{array}{l}3.924 \\
4.504 \\
4.717 \\
5.197 \\
6.766 \\
6.938 \\
7.343 \\
9.314 \\
9.433 \\
9.478 \\
9.605 \\
9.985 \\
11.428 \\
12.305 \\
12.651\end{array}$ & $\begin{array}{l}1961 \\
1964 \\
1965 \\
1967 \\
1979 \\
1981 \\
1985 \\
1996 \\
1997 \\
1997 \\
1998 \\
2000 \\
2006 \\
2010 \\
2012\end{array}$ & $\begin{array}{l}\text { Patrimônio Arquológico } \\
\text { Estatuto da Terra } \\
\text { Ação Popular } \\
\text { Proteção à Fauna } \\
\text { Parcelamento solo urbano } \\
\text { PNMA } \\
\text { Ação Civel Pública } \\
\text { Alteração do Código de Minas } \\
\text { Política Nacional de Águas } \\
\text { Política Nacional de Energia } \\
\text { Crimes Ambientais } \\
\text { Institui Sistema Nacional de Unidades de conservação } \\
\text { Proteção a Mata Atlântica } \\
\text { Política Nacional de Resíduos } \\
\text { Novo Código Florestal }\end{array}$ \\
\hline Resoluções CONAMA & $\begin{array}{c}1 \\
6 \\
9 \\
5 \\
1 \\
3 \\
8 \\
237 \\
281 \\
357 \\
371 \\
382 \\
397 \\
420 \\
428 \\
430\end{array}$ & $\begin{array}{l}1986 \\
1986 \\
1987 \\
1989 \\
1990 \\
1990 \\
1990 \\
1997 \\
2001 \\
2005 \\
2006 \\
2006 \\
2008 \\
2009 \\
2010 \\
2011\end{array}$ & $\begin{array}{l}\text { Licenciamento Ambiental } \\
\text { Pedido de Licenciamento } \\
\text { Realização de Audiências Públicas } \\
\text { Programa Nacional de Controle da Poluição do ar } \\
\text { Padrões e controle de emissão de ruídos } \\
\text { Padrões e controle para poluição do Ar } \\
\text { Limites máximos de emissão de poluentes no ar } \\
\text { Procedimentos para o licenciamento ambiental } \\
\text { Modelos de publicação para licenciamento } \\
\text { Classificação de corpos d'agua e padrões de lançamento } \\
\text { Cálculo para compensação ambiental } \\
\text { Limites máximos de emissão atmosférica de fontes fixas } \\
\text { Altera a classificação de corpos d'agua e padrões de lançamento } \\
\text { Estabeleçe padrões de gerenciamento de solos contaminados } \\
\text { Anuência de Unidades de Conservação no licenciamento } \\
\text { Condições para lançamento de efluentes em corpos d'água }\end{array}$ \\
\hline $\begin{array}{l}\text { Instruções } \\
\text { Normativas do } \\
\text { MMA/IBAMA }\end{array}$ & $\begin{array}{c}253 / 112 \\
146 \\
6 \\
1\end{array}$ & $\begin{array}{l}2006 \\
2007 \\
2013 \\
2015\end{array}$ & $\begin{array}{l}\text { Controle de extração de vegetação } \\
\text { Manejo de Fauna silvestre } \\
\text { Define o Cadastro Técnico Federal } \\
\text { Procedimentos do IPHAN no licenciamento ambiental }\end{array}$ \\
\hline
\end{tabular}

Fonte: Adaptado de Polar (2016). 
Situações específicas, segundo Freire (2009), devem ser observadas no processo de licenciamento:

1. Por ser empreendimento linear e de grandes extensões, gasodutos normalmente afetam fragmentos de florestas nativas, sendo necessária a solicitação de Licença de Supressão de Vegetação ao órgão ambiental;

2. Pro ser de responsabilidade do empreendedor a realização e apresentação dos estudos ambientais, que tem como base Termos de Referências definidos pelo órgão licenciador, sendo tais estudos contratados junto às empresas de consultoria especializadas e devidamente cadastradas no Cadastro Técnico Federal de Atividades e Instrumentos de Defesa Ambiental, junto ao IBAMA;

3. Para cada etapa do licenciamento, são necessários estudos específicos. Os principais estudos elaborados visando subsidiar as etapas do processo de licenciamento, e consequente a obtenção de cada licença, são: (i) Estudo de Impacto Ambiental (EIA) e respectivo Relatório de Impacto Ambiental (RIMA), para fase de obtenção da L.P.; (ii) o Plano Básico Ambiental (PBA), para fase de obtenção da L.I.; (iii) Relatórios de Condicionantes das licenças L.P. e L.I., incluindo os relatórios de atendimento aos Programas Ambientais do PBA, todos para fase de obtenção da L.O.;

4. Durante o processo de licenciamento, são consultados diversos órgãos envolvidos no processo, sejam ambientais ou de proteção.

No caso de consulta aos órgãos envolvidos, segundo Caldas (2006), nos licenciamentos de empreendimentos dutoviários desenvolvido pela Petrobras, a autora destacou as consultas realizadas e pedidos de anuência, pelo órgão ambiental licenciador, às seguintes entidades:

- Anuência da Fundação Cultural Palmares (FCP) em relação às Terras e Comunidades Quilombolas afetadas pelo empreendimento;

- Anuência da Secretaria do Patrimônio da União / Gerência Regional do Patrimônio da União: quando o empreendimento ou atividade se localizar em áreas de domínio da União;

- Autorização do administrador de qualquer Unidade de Conservação afetada pelo empreendimento;

- Anuência da Fundação Nacional do Índio (FUNAI) em relação às Terras e Comunidades Indígenas afetadas pelo empreendimento; 
- Consulta ao Instituto do Patrimônio Histórico e Artístico Nacional (IPHAN) quando diagnosticada a presença de sítios arqueológicos. Inclui o Projeto de Salvamento do Patrimônio Arqueológico;

- Apresentação do comprovante de titularidade da área/instalação física;

- Autorização para uso temporário de vias públicas junto à Polícia Rodoviária e/ou órgão Municipal Competente;

- Autorização para uso e transporte de explosivos, junto ao Ministério do Exército - Serviço de Fiscalização de produtos Controlados;

- Concessão do Departamento Nacional de Produção Mineral (DNPM), no caso de utilização de recurso mineral de emprego em construção civil. Além disso, para o caso de dutos é necessária à solicitação do bloqueio a emissão de novos títulos minerários na faixa de servidão do duto;

- Manifestação da Fundação Nacional da Saúde (FUNASA) se o empreendimento localiza-se em área de risco quanto à transmissão de malária;

- Solicitação a Agência Nacional do Petróleo (ANP) da Autorização de Construção (AC) e Autorização de Operação (AO), indicando que a empresa está apta a construir e operar instalações de transporte ou de transferência de gás natural;

- Autorização de Órgãos Estaduais Gestores de Recursos Hídricos para a realização de travessias e para a captação de água nos rios de domínio estadual, principalmente para realização de Testes Hidrostáticos;

- Autorização dos órgãos responsáveis pelas rodovias e ferrovias para realização de intervenções/cruzamentos das áreas de domínio das rodovias e ferrovias. 


\section{Estudos Ambientais}

Os estudos ambientais necessários para subsidiar o processo de licenciamento, definidos a partir de instrumentos legais, visam o fornecimento de informações e análises técnicas e científicas.

Segundo Sánchez (2015), outros estudos ambientais ${ }^{4}$, além do EIA e respectivo RIMA, são requeridos, caso a caso, a exemplo do Plano Básico Ambiental (PBA), Plano e Relatório de Controle Ambiental, Relatório Ambiental Preliminar, Diagnostico Ambiental Simplificado, Plano de Manejo, Plano de Recuperação de Área Degradada e Análise Preliminar de Risco, dentre outros.

Sánchez (2015) destaca ainda que o EIA é um estudo de maior abrangência que o RIMA (sendo esse praticamente um relatório consolidado do outro), e compreende levantamentos da bibliografia científica e legal pertinente (dados indiretos), como também os resultados dos levantamentos em campo, análises de laboratório (dados diretos), ambos relacionados ao diagnóstico ambiental, necessário para entendimento da questão e realização de avaliações de impacto ambiental.

O Relatório final desses estudos é normalmente redigido em linguagem científica e técnica, sendo complexo e extremamente detalhado, muitas vezes com linguagem, dados e apresentações incompreensíveis para as pessoas mais simples ou de pouco entendimento de questões técnico-científicas, tornando-se ininteligível para esse tipo de público, normalmente afetado pela implantação de empreendimentos (SÁNCHEZ, 2015).

Por outro lado, o referido autor destaca que o RIMA é destinando ao entendimento direto e simplificado por parte das pessoas mais simples ou de pouco entendimento de questões técnico-científicas. Esse relatório, escrito em linguagem simples e com recursos visuais abundantes, busca esclarecer vantagens e as consequências ambientais do empreendimento, além de apresentar conclusões que permitem reflexões, sendo importante instrumento de comunicação e divulgação geral, fundamental para subsidiar as discussões durante as Audiências Públicas (SÁNCHEZ, 2015). 
Além dos estudos anteriormente citados, há que destacar o PBA como importante ferramenta de gestão e controle ambiental durante a implantação dos empreendimentos, basicamente composto pelo detalhamento dos Programa Ambientais, destacando as diretrizes e medidas mitigadoras e compensatórias referentes aos impactos ambientais identificados na AIA.

Em relação aos Relatórios de atendimento às Condicionantes de licença (L.P., L.I. e L.O.), incluindo os relatórios de atendimento aos Programas Ambientais do PBA, destaca-se que os mesmos são decorrentes de exigências específicas dos órgãos ambientais e das exigências definidas para implementação dos Programas, todos definidos durante o processo de licenciamento, e buscam meramente apresentar resultados.

Conforme destacado anteriormente, não excluindo demais estudos, são apresentados a seguir as principais características daqueles essenciais ao processo de licenciamento de gasodutos, quais sejam: Estudo de Impacto Ambiental (EIA), incluindo a de Avaliação de Impactos Ambientais - AIA, o respectivo Relatório de Impacto Ambiental (RIMA) e o Plano Básico Ambiental (PBA), destacando que esse último é objeto de avaliação dessa monografia.

\subsection{Avaliação de Impacto Ambiental - AIA}

Como importante instrumento de Política Ambiental, conforme apresentado anteriormente, a Avaliação de Impacto Ambiental (AIA) foi inicialmente utilizada nos Estados Unidos em 1969, sendo posteriormente utilizado, pela sua importância, na França, Canadá, Holanda, Grã-Bretanha e Alemanha. No Brasil, foi formalmente introduzida a partir da Política Nacional de Meio Ambiente (BRASIL, 1981).

A AIA, segundo Sanches (2015), é um instrumento de política ambiental que define procedimentos visando assegurar a identificação e avaliação de possíveis impactos provocados pelo empreendimento (nas suas diversas fases planejamento, implantação e operação), bem como a apresentação dos resultados de forma adequada às partes interessadas, subsidiando, de forma técnica e científica, a tomada de decisão aos envolvidos no processo.

Nesse aspecto, Sanches (2015) ressalta que o processo decisório visa prevenir danos ambientais de forma geral (ao meio sócio econômico, biótico e

\footnotetext{
${ }^{4}$ O termo "estudos ambientais" foi definido pela resolução CONAMA n²37 de 1997 para englobar estas diferentes denominações.
} 
físico $)^{5}$, destacando que tal prevenção requer antecipação da provável situação futura. A AIA, além de ser adotada por países, regiões e governos legais, também é adotada por organizações que fomentam desenvolvimento, como bancos de desenvolvimento, e por entidades privadas. É reconhecida internacionalmente hoje em dia como um mecanismo eficaz na prevenção de danos ambientais e na promoção do desenvolvimento sustentável.

No Brasil, a utilização da AIA, a partir de determinação legal (Política de Meio Ambiente), é bastante difundida, sendo primordialmente utilizada nos Estudos de Impacto Ambiental (EIA) para avaliação ambiental de empreendimentos, considerando sua instalação e operação, subsidiando sobremaneira a tomada de decisão dos órgãos ambientais sobre a viabilidade ambiental dos mesmos, garantindo também a sua gestão ambiental a partir de compromissos definidos no EIA, de forma contínua durante todo o ciclo de vida do empreendimento (SÁNCHEZ, 2015).

Marriot (1997), destaca que a AIA é realizada em três etapas: identificação, previsão e interpretação da importância dos impactos ambientais relevantes. Dentre os aspectos favoráveis na AIA, segundo o autor, pode-se identificar:

- Caracterização dos aspectos impactantes, agrupados nos meios físico, biótico e antrópico, decorrentes das atividades do empreendimento, variando com suas características e etapas.

- Auxílio na seleção da alternativa locacional mais viável ambientalmente A análise de alternativas é a essência do Estudo de Impacto Ambiental.

- Análise dos impactos ambientais a partir do diagnóstico ambiental e caracterização do empreendimento, definindo o grau de impactos, efeitos diretos e indiretos, efeitos cumulativos, e os de curto e longo prazo.

- Definição de medidas potenciais de mitigação são discutidas e exploradas.

${ }^{5}$ As Resoluções CONAMA 01/86 e 237/97 distinguem os três meios considerados: Meio Socioeconômico (compreende os fatores sociais, econômicos e culturais), Meio Biótico (conjunto definido pelas interações de componentes predominantemente bióticos - fauna e flora) e Meio Físico (conjunto definido pelas interações de componentes predominantemente abióticos - solos, rochas, água e ar) 
No Brasil, Moreira (1991), de forma mais estruturada, estabeleceu seis etapas para realização da AIA:

- Diagnóstico Ambiental das áreas de influências (direta e indireta);

- Identificação dos impactos ambientais, positivos e negativos, prováveis;

- Previsão e dimensionamento dos impactos identificados;

- Valoração e interpretação os impactos previstos;

- Identificação das medidas para eliminar e mitigar impactos, além de definir requisitos para monitoramento;

- Comunicação aos usuários da informação sobre os impactos, tais como os responsáveis pela tomada de decisões e sociedade organizada.

Outro aspecto fundamental no processo de AIA é a escolha e uso de metodologias de avaliação de impactos. De forma geral, tais metodologias buscam comparar, organizar e analisar informações no processo de avaliação, incluindo formas diversas de apresentação (escrita e visual) (TOMMASI, 1993).

Segundo o Tommasi (1993), as metodologias de AIA devem incorporar critérios objetivos visando a integração dos aspectos físicos, bióticos e socioeconômicos a partir do fator tempo, prospecção e setorização adequada do território; critério unificado para soma dos impactos parciais visando a obtenção do impacto total; uso de escalas adequadas nas análises e considerar a participação pública nas tomadas de decisões. Seguem, a seguir, as metodologias normalmente utilizadas na AIA:

Tabela 5: Principais Ferramentas de Avaliação de Impactos Utilizadas na AIA

\begin{tabular}{|c|c|}
\hline \multicolumn{2}{|c|}{ Principais metodologias utilizadas na AIA } \\
\hline TIPO & APLICAÇÃO \\
\hline Métodos Ad Hoc & $\begin{array}{l}\text { Avaliações em tempo curto e quando há carência de dados. } \\
\text { Análise prévia dos impactos de um projeto; } \\
\text { Fornecem orientação para outras avaliações. }\end{array}$ \\
\hline Listagens de Controle Simples & $\begin{array}{l}\text { Diagnóstico ambiental da área de influência. } \\
\text { Identificação dos impactos. }\end{array}$ \\
\hline Listagens de Controle Descritivas & $\begin{array}{l}\text { Diagnóstico ambiental da área de influência; } \\
\text { Análise dos impactos. }\end{array}$ \\
\hline Listagens de Controle Escalares & $\begin{array}{l}\text { Diagnóstico ambiental; } \\
\text { Comparação de alternativas. }\end{array}$ \\
\hline $\begin{array}{l}\text { Listagens de Controle Escalares } \\
\text { ponderadas }\end{array}$ & $\begin{array}{l}\text { Diagnóstico ambiental; } \\
\text { Valoração dos impactos; } \\
\text { Comparação de alternativas. }\end{array}$ \\
\hline Matrizes de Interação & Identificação dos impactos ambientais diretos. \\
\hline Redes de interação (Networs) & $\begin{array}{l}\text { Identificação dos impactos ambientais diretos e indiretos (secundários, } \\
\text { terciários,etc) } \\
\text { Recomendado para pequenos projetos, com poucas alternativas. }\end{array}$ \\
\hline Superposição de Mapas (Overlays) & $\begin{array}{l}\text { Projetos lineares - escolha de alternativas de menor impacto } \\
\text { Diagnósticos ambientais. } \\
\text { Planejamento territorial. }\end{array}$ \\
\hline Modelos de simulação & $\begin{array}{l}\text { Diagnósticos e prognósticos da qualidade ambiental da área de influência. } \\
\text { Comparação de alternativas n- cenários } \\
\text { Projetos de grande porte. }\end{array}$ \\
\hline
\end{tabular}

Fonte: Tommasi (1993) 
Segundo Mariott (1997), pode-se utilizar mais de uma metodologia de AIA considerando as características e especificidades de cada empreendimento, o tempo, os dados e os recursos disponíveis pelo empreendedor e, acima de tudo, a escolha passa a ser em função de atendimento aos requisitos e normas legais definidos para realização dos estudos ambientais. São aspectos importantes que devem ser observados no processo de AIA:

A definição da área de influência do empreendimento é um dos objetivos da AIA. Segundo Sánchez (2015), a previsão de impactos é fundamental para discussão e definição das áreas de influência do empreendimento, considerando que nessa área é onde são detectados os impactos de um empreendimento;

- No processo de avaliação, impactos são identificados, suas magnitudes previstas, avaliadas as suas importâncias, além de ser previsto o alcance geográfico de cada um deles, essencial para descrevê-los e para a discussão da significância dos mesmos;

- As medidas mitigadoras de impactos identificados devem ser contempladas nas ações propostas;

- A mitigação visa inicialmente a eliminação do impacto ao longo do tempo. Não sendo eliminado, o mesmo deve ser minimizado e limitando o grau e/ou a sua magnitude;

- A reparação do impacto, com a restauração e reabilitação do local afetado, deve ser considerada;

- Atendendo aos requisitos legais, deve ser prevista compensação ambiental dos impactos;

Por fim, Sánchez (2015) destaca que a mitigação de impactos é o principal processo na AIA, chegando, em muitos casos, à mitigação aceitável (quando não são eliminados) de impactos adversos a partir de medidas adequadas propostas no âmbito do projeto do empreendimento.

No caso de projetos dutoviários, normalmente implementados pela PETROBRAS, Camarinho (2008) destaca que as empresas especializadas em elaboração de estudos ambientais veem utilizando matrizes de avaliação de impactos baseadas na Matriz de Leopold, que correspondem a uma listagem bidimensional para identificação dos impactos, permitindo ainda a atribuição de valores de magnitude e importância para cada tipo de impacto, de acordo com a fase em que se encontrar o empreendimento (implantação e/ou operação),e com as áreas de influência (direta ou indireta). 


\subsection{Estudos Ambientais - EIA e o RIMA}

Esses dois estudos são elaborados tendo como base o processo da Avaliação de Impactos Ambientais (AIA). Tais estudos estabelecem atividades de diagnóstico ambiental; identificação, medição, interpretação e a quantificação dos impactos (aqui utilizada a AIA); proposição de medidas mitigadoras na forma de programas ambientais, necessários para monitorar e medir resultados das medidas mitigadoras (BRASIL, 1997).

O EIA e o RIMA definem a viabilidade ambiental do empreendimento, sendo essencial para subsidiar as análises do órgão ambiental visando a concessão, ou não, da Licença Prévia do empreendimento, habilitando-o na continuação do processo de licenciamento, visando as etapas de implantação (a partir da concessão da L.I.) e operação (a partir de concessão da L.O.).

Tais estudos são feitos por equipe multidisciplinar, e cumprem o princípio da publicidade, permitindo a participação pública na aprovação dentro do processo de licenciamento ambiental, principalmente nas audiências públicas, aberta ao público em geral, mas visando, sobretudo as comunidades afetadas, direta e indiretamente, pela instalação do empreendimento.

A Resolução CONAMA 01/86, no Artigo 20, item "V", define a realização de EIA/RIMA para licenciamentos de "Oleodutos, gasodutos...", e no Artigo $5^{\circ}$ estabelece diretrizes gerais para elaboração dos mesmos, contemplando:

1. Alternativas tecnológicas e de localização do empreendimento, contemplando a avaliação de não realização do mesmo;

2. Identificação e avaliação de impactos, nas fases de implantação e operação (aqui utilizando a AIA);

3. Definição de limites da área geográfica a ser afetada direta ou indiretamente pelos impactos, denominada área de influência do projeto;

4. Verificação de Planos e Programas governamentais;

5. Realização de diagnóstico ambiental desta área caracterizando-a antes da implantação do empreendimento, levando em conta as variáveis suscetíveis de sofrer, direta ou indiretamente, efeitos significativos das ações em todas as fases do empreendimento considerando:

a) o meio físico - o subsolo, as águas, o ar e o clima, destacando os recursos minerais, a topografia, os tipos e aptidões do solo, os corpos d'água, o regime hidrológico, as correntes marinhas, as correntes atmosféricas;

b) o meio biológico e os ecossistemas naturais - a fauna e a flora, destacando as espécies indicadoras da qualidade ambiental, de valor científico e 
econômico, raras e ameaçadas de extinção e as áreas de preservação permanente;

c) o meio socioeconômico - o uso e ocupação do solo, os usos da água e a sócio economia, destacando os sítios e monumentos arqueológicos, históricos e culturais da comunidade, as relações de dependência entre a sociedade local, os recursos ambientais e a potencial utilização futura desses recursos.

6. Análise dos impactos ambientais do projeto e de suas alternativas, através de identificação, previsão da magnitude e interpretação da importância dos prováveis impactos relevantes, discriminando: os impactos positivos e negativos (benéficos e adversos), diretos e indiretos, imediatos e a médio e longo prazos, temporários e permanentes; seu grau de reversibilidade; suas propriedades cumulativas e sinérgicas; a distribuição dos ônus e benefícios sociais.

7. Definição das medidas mitigadoras dos impactos negativos, entre elas os equipamentos de controle e sistemas de tratamento de despejos, avaliando a eficiência de cada uma delas.

8. Elaboração do programa de acompanhamento e monitoramento dos impactos positivos e negativos, indicando os fatores e parâmetros a serem considerados.

Essa mesma Resolução estabelece que deverão ocorrer por conta do empreendedor a as despesas e custos referentes à realização do estudo de impacto ambiental, entendendo ser a contratação de empresa especializada (especialistas em diversas áreas) visando garantir imparcialidade e, em muitos casos, adequação do empreendimento aos aspectos legais ambientais.

Já o Relatório de Impacto ambiental (RIMA), de acordo com o Artigo $9^{\circ}$ da Conama 01/86, será elaborado em linguagem simples e refletirá as conclusões do estudo de impacto ambiental, contendo no mínimo:

1. Os objetivos e justificativas do projeto, sua relação e compatibilidade com as políticas setoriais, planos e programas governamentais;

2. A descrição do projeto e suas alternativas tecnológicas e locacionais, especificando para cada um deles, nas fases de construção e operação a área de influência, as matérias primas, e mão-de-obra, as fontes de energia, os processos e técnica operacionais, os prováveis efluentes, emissões, resíduos de energia, os empregos diretos e indiretos a serem gerados;

3. A síntese dos resultados dos estudos de diagnósticos ambiental da área de influência do projeto; 
4. A descrição dos prováveis impactos ambientais da implantação e operação da atividade, considerando o projeto, suas alternativas, os horizontes de tempo de incidência dos impactos e indicando os métodos, técnicas e critérios adotados para sua identificação, quantificação e interpretação;

5. A caracterização da qualidade ambiental futura da área de influência, comparando as diferentes situações da adoção do projeto e suas alternativas, bem como com a hipótese de sua não realização;

6. A descrição do efeito esperado das medidas mitigadoras previstas em relação aos impactos negativos, mencionando aqueles que não puderam ser evitados, e o grau de alteração esperado;

7. O programa de acompanhamento e monitoramento dos impactos;

8. Recomendação quanto à alternativa mais favorável (conclusões e comentários de ordem geral).

Essa Resolução ainda estabelece que o RIMA "deve ser apresentado de forma objetiva e adequada a sua compreensão. As informações devem ser traduzidas em linguagem acessível, ilustradas por mapas, cartas, quadros, gráficos e demais técnicas de comunicação visual, de modo que se possam entender as vantagens e desvantagens do projeto, bem como todas as consequências ambientais de sua implementação."

Por fim, de acordo com o Artigo 225 da Constituição Brasileira, 1988, deverá ser dada publicidade a partir de publicação, principalmente em jornais de grande circulação, podendo ser veiculado em rádio e televisão, quando for o caso.

\subsection{O Plano ou Projeto Básico Ambiental - PBA}

O Plano ou Projeto Básico Ambiental (PBA) ${ }^{6}$ não consta explicitamente nas principais resoluções de licenciamento, CONAMAS 01 e 237 (apenas referencia a Planos Programas), que estabelece a realização de estudos ambientais. Posteriormente, com a necessidade de sistematizar os Programas Ambientais, elaborados para mitigar impactos adversos dos empreendimentos, foi elaborada pelo IBAMA a Instrução Normativa 65 (IBAMA, 2006) com base na Resolução CONAMA 06 (setembro de 1987), que estabelece procedimentos para licenciamento de empreendimentos do setor elétrico (Vincentini, 2013), sendo estendido para uso em empreendimentos rodoviários e ferroviários,

\footnotetext{
${ }^{6}$ Foi encontrado o uso de ambas as nomenclaturas em licenças ambientais, sendo que ambos se referem a Planos e Programas ambientais.
} 
posteriormente para Gasodutos, como por exemplo o Gasoduto Bolívia Brasil (Site da TBG, 2018).

A exigência do PBA e o seu reconhecimento enquanto documento técnico formal necessário ao processo de licenciamento aparece nos manuais de licenciamento ambiental do órgão ambiental federal, especificamente o Guia de Procedimentos do Licenciamento Ambiental, capítulo 4 - Documentos técnicos para licenciamento (MMA - IBAMA, 2002), que defino o PBA como "o documento que apresenta, detalhadamente, todas as medidas de controle e os programas ambientais propostos no EIA. Deve ser apresentado para a obtenção da Licença de Instalação". Já no Guia Prático do Licenciamento Ambiental Federal - LAF (MMA-IBAMA, 2018), o PBA tem destaque na análise do requerimento de solicitação da $\mathrm{LI}$, como na análise do requerimento da $L O$, nesse caso sendo o PBA revisado para aplicação durante a operação do empreendimento.

De forma geral, no licenciamento de Dutos, a proposta de PBA sempre é apresentada no EIA, sendo posteriormente detalhada e apresentada no requerimento da L.I., conforme verificado em onze empreendimentos de gasodutos (Site do IBAMA, 2018), onde a documentação principal de licenciamento encontra-se disponível para consulta conforme figura 5 apresentada a seguir:

Figura 5: Empreendimento / Gasodutos Licenciados pelo IBAMA.

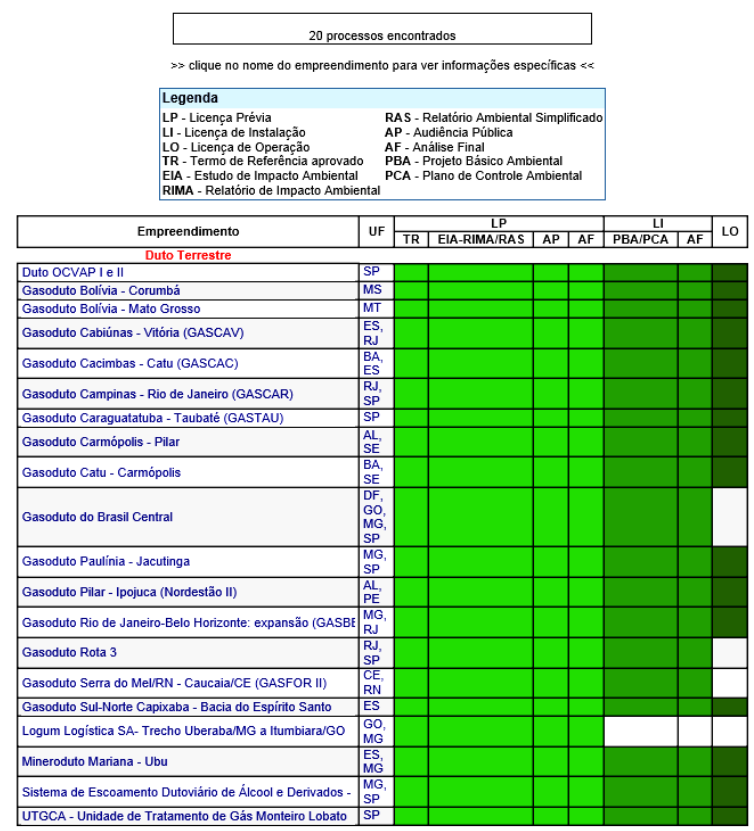

Fonte: Adaptado Site do IBAMA (2018) 
$\mathrm{Na}$ consulta, foi verificado que os empreendimentos tiverem seus licenciamentos (considerando a obtenção das licenças necessárias) no período de 1997 (o primeiro empreendimento que se utilizou a CONAMA 237/99) a 2010 (último empreendimento em processo de licenciamento), conforme tabela 6 a seguir apresentada:

Tabela 6: Lista de Gasodutos Licenciados pelo IBAMA

\begin{tabular}{|c|c|c|c|c|c|c|}
\hline Item & Empreendimento / Gasoduto & Empreendedor & emissão da LP & emissão da LI & emissão da LO & $\begin{array}{c}\text { Existencia de Condicionante na LP } \\
\text { solicitando PBA }\end{array}$ \\
\hline 1 & Brasil Central & TGBC & ago/10 & nov/13 & em andamento & Sim \\
\hline 2 & GASBEL II & TAG & jan/08 & $\mathrm{dez} / 08$ & out $/ 10$ & Sim \\
\hline 3 & Pilar / Ipojuca & PETROBRAS & $\mathrm{jul} / 08$ & $\mathrm{dez} / 08$ & $\mathrm{dez} / 10$ & Sim \\
\hline 4 & Caraguatatuba / Taubaté & TAG & out/07 & mar/09 & $\operatorname{mar} / 11$ & Sim \\
\hline 5 & Paulinia - Jacutinga & PETROBRAS & out/07 & jun/08 & nov/09 & Sim \\
\hline 6 & Cacimbas / Catu & PETROBRAS & $\mathrm{dez} / 06$ & $\mathrm{dez} / 07$ & $\mathrm{mar} / 10$ & Sim \\
\hline 7 & Catu / Carmópolis & PETROBRAS & jun/05 & out/05 & $\mathrm{dez} / 14$ & Sim \\
\hline 8 & Carmópolis / Pilar & PETROBRAS & $\mathrm{dez} / 04$ & mar/05 & set/07 & Sim \\
\hline 9 & Campinas / RJ & PETROBRAS & nov/03 & jun/04 & jul/07 & Sim \\
\hline 10 & GASCAV & PETROBRAS & out/99 & mai/05 & jan/08 & Sim \\
\hline 11 & GASBOL & PETROBRAS & jul/97 & julho/97 e mar/98 & mar/00 & $\operatorname{sim}$ \\
\hline
\end{tabular}

Fonte: Site do IBAMA (2018)

Em todas LP verificadas constavam condicionantes específicas, estabelecendo a exigência dos Planos e Programas para mitigação de impactos ambientais. Nos dois primeiros empreendimentos licenciados (GASBOL, em 1997/2000 e GASCAV, em 1999/2008), não constava a nomenclatura PBA. A partir do licenciamento do gasoduto Campinas / RJ, passou-se a utilizar a referida nomenclatura nas condicionantes da L.P., com a seguinte redação:

"Apresentar o Projeto Básico Ambiental (PBA) com o detalhamento de todos programas ambientais / medidas mitigadoras consignadas no EIA e nesta licença Prévia, contendo justificativas, objetivos, metas, indicadores ambientais, público alvo. Metodologia, descrição do programa, atividades, responsáveis técnicos, instituições envolvidas, cronograma físico-financeiro de execução, inter-relacionamento com outros programas e, quando exigível, atendimentos legais para a sua efetiva implantação. "

Dessa forma, o PBA passou a ser uma importante ferramenta de gestão ambiental, tendo em vista a exigência de metas e indicadores, na forma de Planos e Programas, para a implantação de empreendimentos de dutos. Para o caso de gasodutos, são definidos os seguintes Planos e Programas nos PBA (IBAMA, 2008):

- Sistema de Gestão Ambiental: visa a definição de mecanismos que garantam a execução e o controle de ações definidas nos Planos e Programas;

- Programa de Comunicação Social: objetiva ligação permanente com empreendedor e comunidades afetas pela implantação do empreendimento. 
- Programa de Educação Ambiental: busca sensibilizar as comunidades das áreas de influência do empreendimento sobre a importância da conservação e preservação ambiental, principalmente em relação à região que estão inseridos.

- Programas de Apoio às obras e Liberação da Faixa de Servidão: Programa de Estabelecimento da Faixa de Servidão Administrativa e de indenizações, Programa de Prospecção Arqueológica, Programa de Educação Patrimonial, Programa de Supressão de vegetação, Salvamento de Germoplasma e reposição florestal; Programa de Gestão de Interferências Minerárias.

- Programas de Supervisão e Controle das Obras: Plano Ambiental da Construção (PAC), Programa de Controle de Processos Erosivos, Programa de Recuperação de Áreas Degradadas, Programa de Controle de Poluição.

- Programas de Monitoramento Ambiental: Programa de Monitoramento da Fauna, Programa de Monitoramento da Flora. 


\section{Estudo de Caso: O PBA do Gasoduto Bolívia-Brasil}

Conforme apresentado anteriormente de forma resumida, as evoluções das discussões acerca da questão ambiental demandaram ações sistemáticas para controlar os impactos ambientais decorrentes da implantação e operação de empreendimentos de significativo impacto ao meio ambiente, entendo os meios socioeconômico, físico e biótico.

Também foram verificados marcos legais e a legislação específica para garantir que tais empreendimentos, de significativamente impacto, se adequassem ambientalmente. No caso da indústria de gás natural, especificamente gasodutos de transporte, verificou-se aspectos de licenciamento ambiental desses empreendimentos, notadamente estudos necessários no processo de licenciamento e, no caso o foco dessa monografia, a ferramenta adotada para a gestão ambiental da implantação do mesmo.

No estudo de caso, será abordada a questão da gestão ambiental da operação de um Gasoduto, a partir de adoção de Plano Básico Ambiental para operação, prela primeira vez adotada, especificamente para o Gasoduto Bolívia - Brasil.

Tal estudo tem como base os dados levantados junto ao órgão ambiental licenciador, no caso o IBAMA; junto a proprietária e operadora do Gasoduto Bolivia Brasil, no caso a TBG, e os dados do Estudo de Impacto Ambiental para o Trecho Brasileiro do Gasoduto Bolívia Brasil: Relatório Consolidado (PETROBRAS, 1997).

\subsection{Características do Gasoduto Bolívia Brasil}

A descrição das características do Gasoduto Bolívia Brasil foi obtida no site da empresa Transportadora Brasileira Gasoduto Bolívia - Brasil S.A. (TBG), dona e operadora desse ativo (Site da TBG, 2018).

Segundo o EIA Consolidado (PETROBRAS, 1997), a construção e operação do Gasoduto Bolívia-Brasil - GASBOL visava o suprimento do gás natural, produzido na Bolívia, para desenvolvimento do mercado brasileiro a 
partir das reservas bolivianas, além de adicionar mais uma fonte de energia à matriz energética brasileira.

O Gasoduto Bolívia Brasil foi construído com tubos de aço carbono, soldados e enterrados a uma profundidade média de um metro, o gasoduto transporta o gás natural proveniente da Bolívia para o Brasil, atravessando os estados de Mato Grosso do Sul, São Paulo, Paraná, Santa Catarina e Rio Grande do Sul. Essa tubulação está localizada numa faixa de terreno com 20 metros de largura, denominada Faixa de Servidão (Site da TBG, 2018).

Segundo a TBG (2018), o Gasoduto tem capacidade de transporte/fornecimento de até 30,08 milhões de metro cúbicos/dia de gás natural, operando, no transporte, em alta pressão (variando de 75 a 100 $\mathrm{kgf} / \mathrm{cm}^{2}$ ). A entrega é feita às Companhias Distribuidoras Locais (CDL), através dos Pontos de Entrega da TBG, a baixa pressão.

O gás natural transportado, segundo a TBG (2018), tem uma grande variedade de utilização. Seus principais usos têm sido como combustível industrial, comercial e residencial, conforme apresentado a seguir:

Tabela 7: Uso do Gás Natural Transportado pelo Gasoduto Bolívia Brasil Tipos de Uso do Gás Natural

Residências, Uso seguro e prático, é acessível via redes públicas das concessionárias comércio e serviços estaduais.

No transporte coletivo e de cargas, substituindo a gasolina e o álcool, contribuindo para redução na poluição atmosférica das grandes cidades

Traz vantagens como melhoria da qualidade final dos produtos; não necessita de aquecimento antes da combustão; possibilita o controle de temperatura, sofre queima completa, elimina gastos com frete e estocagem por ser entregue via duto e uso intenso nas indústrias petroquímica e de fertilizantes.

Intenso uso como combustível na geração de eletricidade, em usinas

Energia termelétricas; Uso em unidades industriais e instalações comerciais; e uso em unidades de serviços, sob regime de cogeração.

Fonte: Site da TBG, 2018

\section{2. $\quad O$ traçado do Gasoduto Bolívia Brasil}

Esse Gasoduto tem início em território Boliviano, se estendendo por 557 km de Porto Suarez até a fronteira do Brasil, em Corumbá/MS. O Trecho brasileiro, com $2.593 \mathrm{~km}$, se estende de Corumbá/MS até Canoas/RS, atravessa os cinco Estados mencionados anteriormente. 
Figura 6: Traçado do Gasoduto Bolívia Brasil - Atualmente

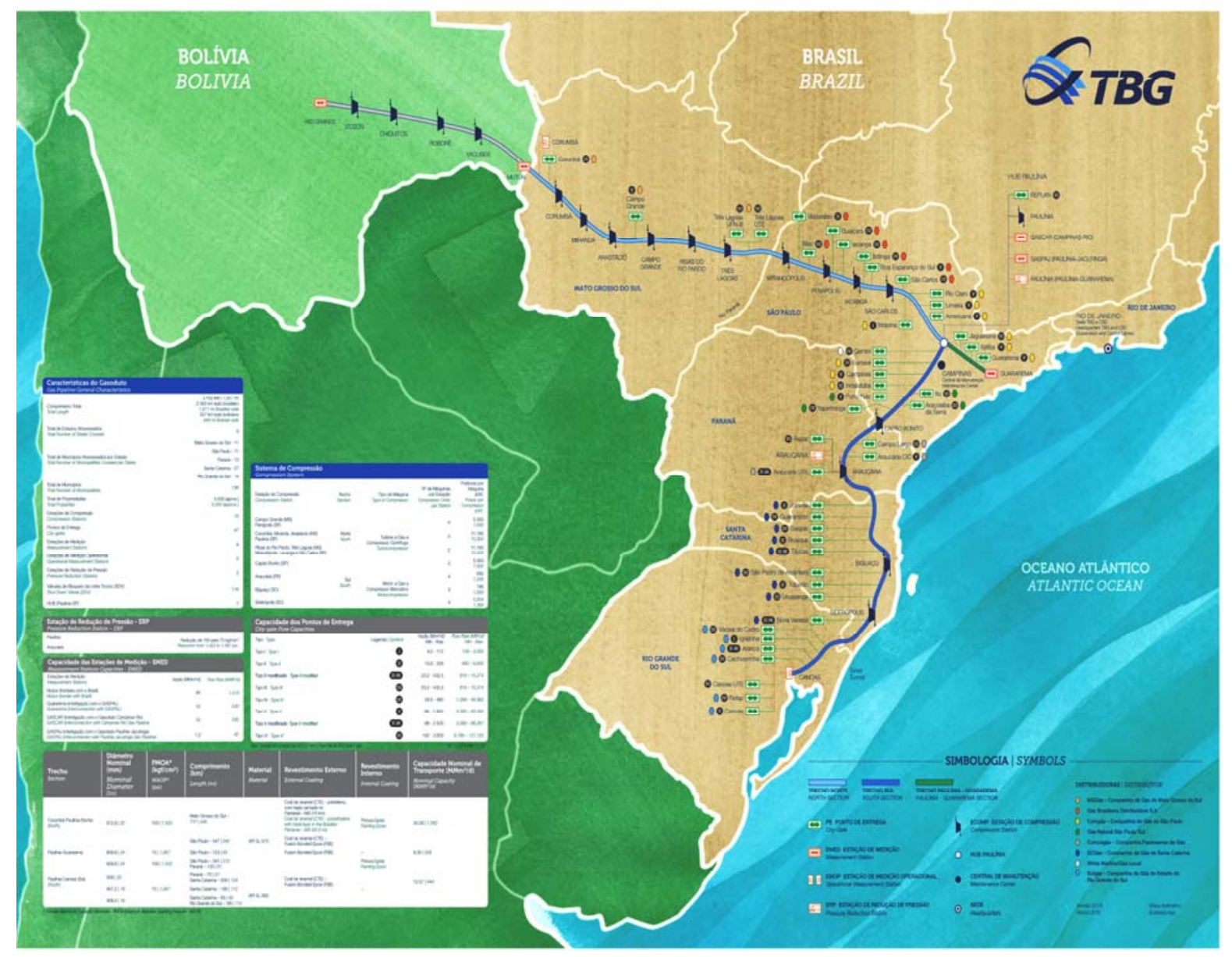

Fonte: Site da TBG, 2018 
Figura 7: Traçado Original do Gasoduto Bolívia Brasil, apresentado no EIA

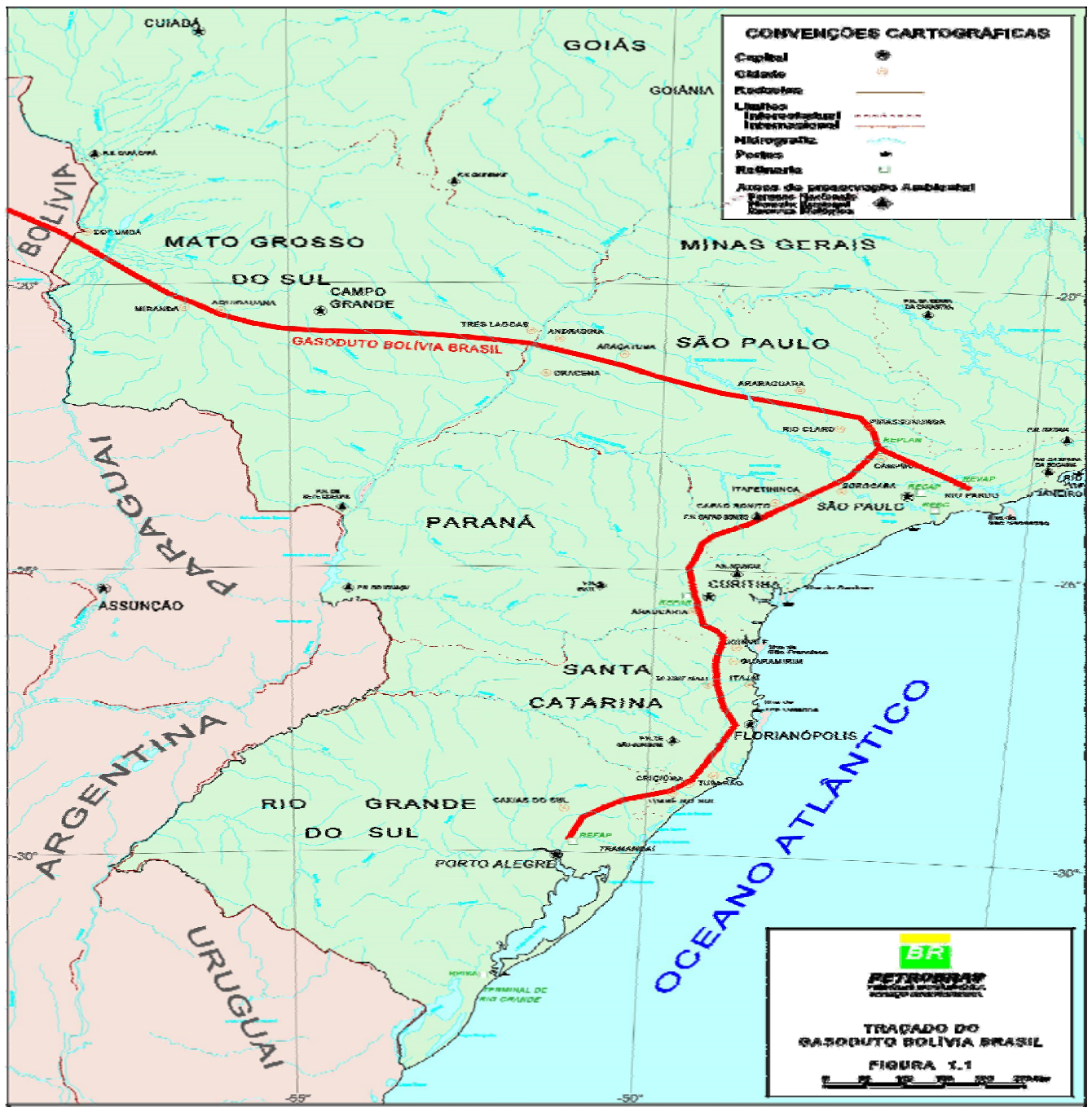

Fonte: Petrobrás (1997)

A travessia pelos 05 Estados Brasileiros significa dizer que são atravessados 13 municípios (cerca de 5.000 propriedades), conforme listado nas tabelas 8 e 9 abaixo (Site da TBG, 2018): 
Tabelas 8 : Estados do Mato Grosso do Sul e São Paulo e respectivos Municípios atravessados

\begin{tabular}{|c|c|}
\hline Estado & Municípios \\
\hline $\begin{array}{c}11 \\
\text { municípios } \\
\text { no Mato } \\
\text { Grosso do } \\
\text { Sul }\end{array}$ & $\begin{array}{l}\text { Corumbá } \\
\text { Miranda } \\
\text { Aquidauana } \\
\text { Anastácio } \\
\text { Dois Irmãos do Buriti } \\
\text { Terenos } \\
\text { Campo Grande } \\
\text { Ribas do Rio Pardo } \\
\text { Santa Rita do Pardo } \\
\text { Brasilândia } \\
\text { Três Lagoas }\end{array}$ \\
\hline
\end{tabular}

\begin{tabular}{|c|c|c|c|c|c|}
\hline Estado & \multicolumn{5}{|c|}{ Municipios } \\
\hline $\begin{array}{c}71 \\
\text { municípios } \\
\text { em São } \\
\text { Paulo }\end{array}$ & $\begin{array}{c}\text { Castilho } \\
\text { Nova Independência } \\
\text { Andradina } \\
\text { Murutinga do Sul } \\
\text { Guaraçaí } \\
\text { Mirandópolis } \\
\text { Lavínia } \\
\text { Valparaíso } \\
\text { Bento de Abreu } \\
\text { Rubiácea } \\
\text { Guararapes } \\
\text { Araçatuba } \\
\text { Bilac } \\
\text { Birigui } \\
\text { Coroados }\end{array}$ & $\begin{array}{c}\text { Glicério } \\
\text { Penápolis } \\
\text { Avanhandava } \\
\text { Promissão } \\
\text { Guaiçara } \\
\text { Lins } \\
\text { Cafelândia } \\
\text { Pongaí } \\
\text { Uru } \\
\text { Pirajuí } \\
\text { Reginópolis } \\
\text { Iacanga } \\
\text { Ibitinga } \\
\text { Boa Esperança do Sul } \\
\text { Ribeirão Bonito }\end{array}$ & $\begin{array}{c}\text { Araraquara } \\
\text { Ibaté } \\
\text { São Carlos } \\
\text { Itirapina } \\
\text { Rio Claro } \\
\text { Santa Gertrudes } \\
\text { Iracemápolis } \\
\text { Limeira } \\
\text { Americana } \\
\text { Cosmópolis } \\
\text { Paulínia } \\
\text { Campinas } \\
\text { Jaguariúna } \\
\text { Valinhos } \\
\text { Itatiba }\end{array}$ & $\begin{array}{c}\text { Morungaba } \\
\text { Jarinu } \\
\text { Bragança Paulista } \\
\text { Atibaia } \\
\text { Bom Jesus dos Perdões } \\
\text { Nazaré Paulista } \\
\text { Santa Isabel } \\
\text { Mogi das Cruzes } \\
\text { Guararema } \\
\text { Monte Mor } \\
\text { Indaiatuba } \\
\text { Salto } \\
\text { Itu } \\
\text { Porto Feliz } \\
\text { Sorocaba }\end{array}$ & $\begin{array}{c}\text { Iperó } \\
\text { Araçoiaba da Serra } \\
\text { Capela do Alto } \\
\text { Sarapuí } \\
\text { Itapetininga } \\
\text { Capão Bonito } \\
\text { Itapeva } \\
\text { Ribeirão Branco } \\
\text { Apiaí } \\
\text { Barra do Chapéu } \\
\text { Itapirapuã Paulista }\end{array}$ \\
\hline
\end{tabular}

Fonte: Site da TBG (2018)

Tabela 9: Estados do Paraná, Santa Catarina e Rio Grande do Sul e respectivos Municípios atravessados pelo Gasoduto

\begin{tabular}{|c|c|}
\hline Estado & Municípios \\
\hline & Doutor Ulysses \\
Cerro Azul \\
Rio Branco do Sul \\
Itaperuçu \\
Campo Magro \\
Almirante Tamandaré \\
\hline $\mathbf{1 3}$ & Campo Largo \\
\hline municípios & Araucária \\
\hline no Paraná & Curitiba \\
& Fazenda Rio Grande \\
& São José dos Pinhais \\
& Tijucas do Sul \\
& Guaratuba \\
& \\
\hline
\end{tabular}

\begin{tabular}{|c|c|c|}
\hline Estado & \multicolumn{2}{|c|}{ Municípios } \\
\hline & Garuva & São Martinho \\
\hline Joinville & Armazém \\
\hline Guaramirim & Gravatal \\
\hline munsaranduba & Tubarão \\
\hline em Santa & Luiz Alves & Pedras Grandes \\
\hline Catarina & Gaspar & Treze de Maio \\
& Brusque & Urussanga \\
& Canelinha & Cocal do Sul \\
& Tijucas & Siderópolis \\
& Bntônuaçu & Nova Veneza \\
& São Pedro de Alcântara & Timbé do Sul \\
& Santo Amaro da Imperatriz & \\
\hline & Águas Mornas & \\
\hline
\end{tabular}

\begin{tabular}{|c|c|}
\hline Estado & Municípios \\
\hline $\begin{array}{l}14 \text { municípios } \\
\text { no Rio Grande } \\
\text { do Sul }\end{array}$ & $\begin{array}{l}\text { São José dos Ausentes } \\
\text { Cambará do Sul } \\
\text { Jaquirana } \\
\text { São Francisco de Paula } \\
\text { Taquara } \\
\text { Igrejinha } \\
\text { Parobé } \\
\text { Nova Hartz } \\
\text { Araricá } \\
\text { Sapiranga } \\
\text { Novo Hamburgo } \\
\text { Gravataí } \\
\text { Cachoeirinha } \\
\text { Canoas }\end{array}$ \\
\hline
\end{tabular}

Fonte: Site da TBG (2018) 


\subsection{Instalações Fixas do Gasoduto Bolívia Brasil}

Para manter em condições ideais o transporte do gás natural e garantir a sua entrega nos Estados, o Gasoduto dispõe de 47 Pontos de Entrega (PE) onde é feita a redução da pressão do gás para proceder a entrega às companhias distribuidoras locais; conta com quatro estações de medição (EMED) e duas estações de medição operacional (responsáveis por medir as variáveis operacionais (pressão, temperatura e vazão), além de 15 Estações de compressão (ECOMP) (Site da TBG, 2018). 
A seguir, são apresentados os $47 \mathrm{PE}$, por Estado atravessado, associadas ao Gasoduto Bolívia Brasil:

Tabela 10: Relação de instalações fixas - PE

\begin{tabular}{|c|c|c|}
\hline Estado & Ponto de Entrega & Companhia Distribuidora Local \\
\hline MS & $\begin{array}{l}\text { PE Corumbá } \\
\text { PE Campo Grande } \\
\text { PE Três Lagoas } \\
\text { PE Três Lagoas UFN - III }\end{array}$ & $\begin{array}{l}\text { MSGÁS - Companhia de Gás do Estado de } \\
\text { Mato Grosso do Sul }\end{array}$ \\
\hline SP & $\begin{array}{l}\text { PE Valparaíso } \\
\text { PE Bilac } \\
\text { PE Guaiçara } \\
\text { PE Iacanga } \\
\text { PE Ibitinga } \\
\text { PE Boa Esperança do Sul } \\
\text { PE São Carlos } \\
\text { PE Itirapina } \\
\text { PE Rio Claro } \\
\text { PE Limeira } \\
\text { PE Americana } \\
\text { PE Jaguariúna } \\
\text { PE Itatiba } \\
\text { PE Guararema } \\
\text { PE Sumaré } \\
\text { PE Campinas } \\
\text { PE Indaiatuba } \\
\text { PE Replan } \\
\text { PE Gemini } \\
\text { PE Itu } \\
\text { PE Porto Feliz } \\
\text { PE Araçoiaba da Serra } \\
\text { PE Itapetininga }\end{array}$ & $\begin{array}{l}\text { Entrega de gás diretamente à Petrobras } \\
\text { Gás Local } \\
\text { Gas Natural Fenosa }\end{array}$ \\
\hline PR & $\begin{array}{l}\text { PE Campo Largo } \\
\text { PE Araucária/CIC } \\
\text { PE Araucária/UTE } \\
\text { PE REPAR }\end{array}$ & $\begin{array}{l}\text { COMPAGAS - Companhia Paranaense de } \\
\text { Gás } \\
\text { Entrega de gás diretamente à Petrobras }\end{array}$ \\
\hline SC & $\begin{array}{l}\text { PE Joinvillle } \\
\text { PE Guaramirim } \\
\text { PE Gaspar } \\
\text { PE Brusque } \\
\text { PE Tijucas } \\
\text { PE São Pedro de Alcântara } \\
\text { PE Tubarão } \\
\text { PE Urussanga } \\
\text { PE Nova Veneza }\end{array}$ & $\begin{array}{l}\text { SCGÁS - Companhia de Gás de Santa } \\
\text { Catarina }\end{array}$ \\
\hline RS & $\begin{array}{l}\text { PE Várzea do Cedro } \\
\text { PE Igrejinha } \\
\text { PE Araricá } \\
\text { PE Cachoeirinha } \\
\text { PE UTE-Canoas* } \\
\text { PE Refap } \\
\text { PE Canoas }\end{array}$ & $\begin{array}{l}\text { SULGÁS - Companhia de Gás do Estado do } \\
\text { Rio Grande do Sul }\end{array}$ \\
\hline
\end{tabular}

Fonte: Site da TBG (2018) 
$\mathrm{Na}$ tabela 11 a seguir, são apresentadas as 15 ECOMP, por Estado atravessado, associadas ao Gasoduto Bolívia Brasil:

Tabela11: Relação de instalações fixas -

\section{ECOMP}

\begin{tabular}{|c|c|}
\hline Estado & Estação de Compressão \\
\hline $\begin{array}{l}\text { Mato Grosso } \\
\text { do Sul }\end{array}$ & $\begin{array}{l}\text { ECOMP Corumbá } \\
\text { ECOMP Miranda } \\
\text { ECOMP Anastácio } \\
\text { ECOMP Campo Grande } \\
\text { ECOMP Ribas do Rio Pardo } \\
\text { ECOMP Três Lagoas }\end{array}$ \\
\hline São Paulo & $\begin{array}{l}\text { ECOMP Mirandópolis } \\
\text { ECOMP Penápolis } \\
\text { ECOMP Iacanga } \\
\text { ECOMP São Carlos } \\
\text { ECOMP Paulínia } \\
\text { ECOMP Capão Bonito }\end{array}$ \\
\hline Paraná & ECOMP Araucária \\
\hline $\begin{array}{l}\text { Santa } \\
\text { Catarina }\end{array}$ & $\begin{array}{l}\text { ECOMP Biguaçu } \\
\text { ECOMP Siderópolis }\end{array}$ \\
\hline
\end{tabular}

Fonte: Site da TBG (2018)

\subsection{Operação e manutenção no Gasoduto Bolívia Brasil}

Para operar de forma contínua os 2.593 quilômetros do Gasoduto, a TBG adota técnicas de operação, inspeção e manutenção, conforme algumas descritas a seguir (Site da TBG, 2018):

- Através de uma Central da Controle localizada na Sede da Empresa, no Rio de Janeiro, a operação do duto e instalações é controla por satélite 24 horas por dia, sendo utilizado o Sistema de Controle Supervisório e de Aquisição de Dados (SCADA) para tal. O SCADA é interligado e operado com o auxílio de Satélite, que centraliza todas as informações e facilita a operação, incluindo Estações de Medição e Controle, visando minimizar falhas humanas e de equipamentos ${ }^{7}$;

- Localizada em Campinas, a TBG conta com uma Central de Manutenção que, estrategicamente, apoia todas as atividades de inspeção e manutenção ao longo do Gasoduto. Essa unidade utiliza a técnica de Manutenção Centrada em Confiabilidade (MCC) para garantir a integridade das instalações;

\footnotetext{
7 Esse sistema tem alto grau de confiabilidade, visto que, além da rapidez de processamento das informações, oferece cobertura total para cada anormalidade que vier a ocorrer.
} 
- Equipes de técnicos, estrategicamente distribuídas, inspecionam periodicamente a faixa de servidão, instalações e equipamentos visando identificar e corrigir possíveis problemas, além manter contatos com a população que vive próximo à faixa;

A TBG (2018), dentre outras ferramentas, adota linha direta 0800, denominada Linha do Gás, que funciona 24 horas por dia, 7 dias por semana, visando manter comunicação com as populações próximas ao duto, como manter transparência de informações sobre as funções do gás natural e o impacto do Gasoduto sobre sua vida, dentre outros esclarecimentos.

A título de exemplo, conforme consta no site da TBG (2018), a população do entorno é estimulada a ligar para a Linha do Gás - 08000260400 - se perceber: danos às placas de sinalização; qualquer tipo de construção na faixa; uso indevido de explosivos nas proximidades; escavações e queimadas suspeitas e sem acompanhamento dos técnicos da TBG; ações da natureza nas proximidades da faixa, tais como: desmoronamento, erosão por chuva, queda de árvores de grande porte, dentre outros. A seguir, apresenta-se o informe que é divulgado às populações próximas à faixa:

Figura 8: Logo da Linha do Gás da TBG

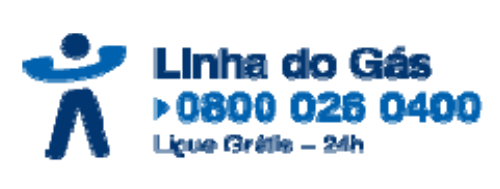

Linha do Gás. O tempo todo com você.

Fonte: Site da TBG (2018)

Segundo a TBG (2018), a faixa de servidão, instituída a partir do Decreto Federal de 28/08/1996, tem largura de 20 metros ao longo dos 2.593 quilômetros do percurso do duto, que encontra-se enterrado. Essa área é fundamental, pois delimita e protege a tubulação do Gasoduto; identifica os locais de instalação de equipamentos e sinaliza os locais onde não se podem fazer escavações, construções, ocupações, queimadas e obras em geral.

Já o duto, nos seus 2.593 quilômetros, foi lançado e enterrado a uma profundidade média de 1 metro. Assim, a faixa é essencial para proteção do duto de possíveis danos ocasionados por terceiros, devendo ser criteriosamente sinalizada e com os acessos livres de obstáculos em toda a sua extensão (Site da TBG, 2018).

Segundo verificado no Site da TBG (2018), a sinalização visa delimitar a faixa de servidão e, com isso, identificar, para as populações lindeiras ou 
qualquer pessoa que chegue próxima à mesma, a localização do Gasoduto da TBG. Para tal, são utilizados marcos delimitadores para definir os limites da faixa de servidão, como marcos quilométricos para indicar a quilometragem do trajeto do Gasoduto. Também são adotadas placas de sinalização que alertam a existência de "Gasoduto enterrado", contribuindo sobremaneira para a segurança do duto em cruzamentos com rodovias, ferrovias, linhas de transmissão e, também, nas travessias de rios, lagos e lagoas. A seguir, apresenta-se elementos de sinalização utilizados na Faixa de servidão da TBG (2018):

Figura 9: Marco delimitador (1); Marco Sinalizador (2) e Placa de sinalização (3).

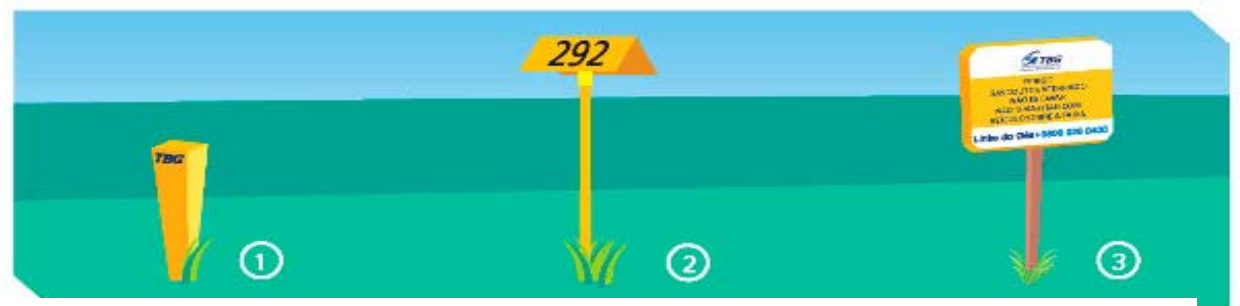

Fonte: Site da TBG (2018)

Para ajudar no processo de informação as populações próximas e proprietários de terras atravessadas pelo gasoduto, a TBG (2018) providencia a entrega, pelos técnicos de faixa, impressos que trazem informações fundamentais para a preservação das pessoas e da integridade do duto, conforme exemplo a seguir:

Figura 10: Guia de convivência, distribuído ao longo da faixa de servidão

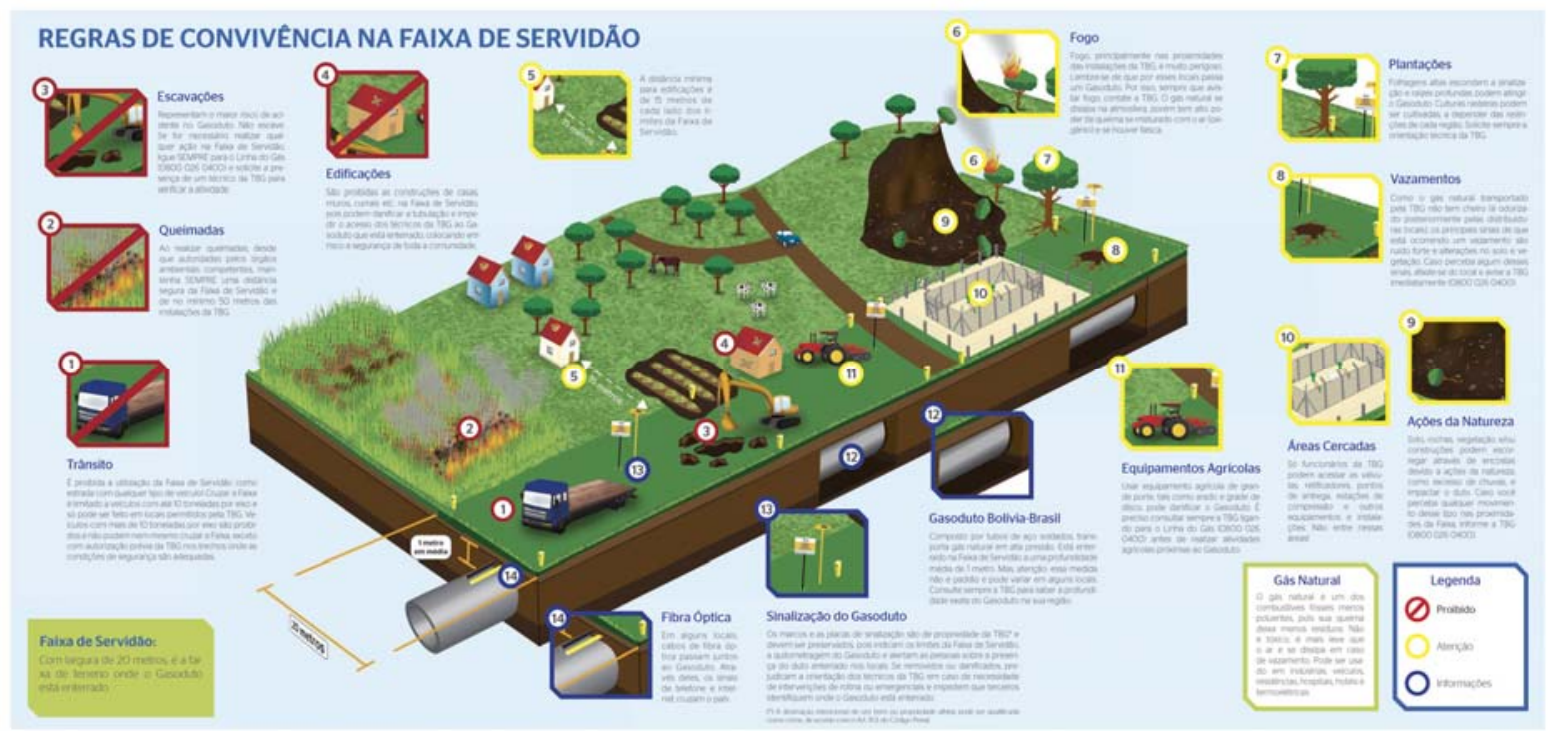

Fonte: Site da TBG (2018) 
Por fim, a Faixa de Servidão é devidamente inspecionada a partir de inspeções aéreas, por helicóptero, Inspeções fluviais, realizada por mergulhadores nos trechos de travessia de rios e lago e Inspeções Terrestres, realizadas ao longo dos dutos por técnicos de faixa (Site da TBG, 2018).

\subsection{Processo de licenciamento do Gasoduto Bolívia Brasil}

Conforme tabela 6, apresentada no item 4.3 dessa monografia, o Gasoduto em questão foi licenciado no período de 1997 (ano de obtenção da L.P.) até março de 2000 (ano de obtenção da L.O. e início da operação como um todo). Destaca-se que o trecho Norte do Gasoduto, considerado desde Corumbá até Campinas/SP, teve operação previamente iniciada em 1990.

Importante ressaltar que uma parte de Gasoduto Bolívia Brasil, cerca de $156 \mathrm{~km}$ em faixa compartilhada com dutos da PETROBAS, foi licenciada pelo órgão estadual de São Paulo, no caso a CETESB (Companhia Ambiental do Estado de São Paulo), por essa razão não foi contemplada sua análise nesse estudo.

Segundo informações do EIA Consolidado (PETROBRAS, 1997- Capítulo 8), o processo de discussão para elaboração dos Estudos Ambientais (EIA/RIMA) visando subsidiara as análises e decisões no processo de licenciamento do Gasoduto Bolívia Brasil, na época denominado GASBOL, foi iniciado em 1992 a partir de um Programa de Consultas Públicas junto aos Órgãos Públicos, às Organizações Não Governamentais (ONGs), à comunidade científica, às associações e aos demais representantes da sociedade civil organizada. Tal Programa objetivou:

- facilitar a discussão dos pontos de vista divergentes acerca do projeto e de seus impactos sobre os Meios Físico, Biótico e Socioeconômico;

- permitir a participação direta dos interessados na busca de soluções para os impactos (medidas minimizadoras ou compensatórias para os impactos negativos e otimizadoras para os positivos) nos processos decisórios, durante o licenciamento ambiental, em atendimento à legislação vigente na época;

- obter dados relativos ao planejamento de ações relacionadas a temas ambientais de responsabilidade dos Órgãos de Governo, relativos à proteção e preservação dos recursos naturais (água, vegetação, fauna, etc.), organização do uso dos solos, planejamento das infraestruturas de saúde e educação, dentre outras; 
- estabelecer diálogo com as ONGs e comunidades atingidas visando promover a compreensão do projeto e de seus desdobramentos, tanto em relação aos impactos, sua natureza, abrangência e mitigações, quanto aos benefícios sociais e econômicos de sua implantação, buscando-se, em conjunto, as melhores formas de otimizá-los, promovendo o desenvolvimento regional.

Segundo consta no EIA Consolidado (PETROBRAS, 1997), como resultado do Programa de Consultas Públicas, foram realizados:

- reuniões com o Instituto Brasileiro do Meio Ambiente e dos Recursos Naturais Renováveis (IBAMA), visando definição do Termo de Referência para o EIA/RIMA e a competência do licenciamento, como reuniões envolvendo os órgãos ambientais dos cinco Estados atravessados pelo Gasoduto;

- Foram encaminhadas 108 cartas às Prefeituras Municipais (dez municípios em Mato Grosso do Sul, quarenta e nove municípios em São Paulo, doze municípios no Paraná, vinte e sete municípios em Santa Catarina e dez municípios no Rio Grande do Sul);

- Foram encaminhadas 33 cartas a Órgãos Federais e Estaduais (Instituto Brasileiro do Patrimônio Cultural - IBPC, Fundação Nacional do Índio - FUNAI, Departamento Nacional de Estradas de Rodagem - DNER, Rede Ferroviária Federal - RFFSA, Capitania dos ;Portos/Marinha do Brasil, Ministério da Saúde, Secretarias Estaduais de Planejamento, Obras, Educação, Saúde e Meio Ambiente, dentre outros);

- Foram realizados inúmeros contatos com ONGs, Associações e representantes da sociedade civil organizada.

O licenciamento junto ao IBAMA foi iniciado em 1992 e o EIA/RIMA entregue aos órgãos ambientais estaduais entre anos de 1993 a 1995, para comentários e complementações, sendo logo em seguida realizadas Audiências Públicas, conforme tabela 12 abaixo:

Tabela 12: Audiências Públicas Realizadas

\begin{tabular}{|c|c|c|}
\hline Estado & Município & Ano de realização \\
\hline Mato Grosso do Sul & $\begin{array}{c}\text { Corumbá } \\
\text { Campo Grande } \\
\text { Três Lagoas }\end{array}$ & $\begin{array}{l}\text { 25/jan/94 } \\
27 / j a n / 94 \\
28 / j a n / 94\end{array}$ \\
\hline São Paulo & $\begin{array}{l}\text { Araçatuba } \\
\text { Campinas }\end{array}$ & $\begin{array}{l}\text { 18/jul/94 } \\
19 / j u l / 94\end{array}$ \\
\hline Paraná & $\begin{array}{l}\text { Curitiba } \\
\text { Araucária }\end{array}$ & $\begin{array}{c}\text { 01/jul/94 } \\
16 / \text { nov/94 }\end{array}$ \\
\hline Santa Catarina & Florianópolis & 07/nov/95 \\
\hline Rio Grande do Sul & Porto Alegre & $19 / \mathrm{dez} / 95$ \\
\hline
\end{tabular}

Referência: PETROBRAS (1997) 
Por exigência do órgão financiado, no caso o Banco Mundial, a PETROBRAS elaborou o Relatório Consolidado do EIA, revendo, analisando e atualizando relatórios e consolidando os Estudos de Impacto Ambiental do Gasoduto Bolívia Brasil, realizados por empresa contratada (produziu 27 volumes), todos formatados de acordo com as Diretrizes desse Banco, de forma a fornecer uma visão integrada do Empreendimento e sua interface com o Meio Ambiente (PETROBRAS, 1997).

A equipe responsável pela revisão, atualização e elaboração deste relatório foi composta por técnicos da PETROBRAS e por Consultores que haviam trabalhado nos estudos originais. O EIA Consolidado foi dividido em seções (PETROBRAS, 1997), conforme descrito a seguir.

\section{Tabela13: Estrutura do EIA Consolidado}

\begin{tabular}{|c|c|c|}
\hline Item & Titulo & Observação \\
\hline CAPÍTULO 1 & INTRODUÇÃO. & $\begin{array}{l}\text { Apresenta-se o histórico, o objetivo e a metodologia do } \\
\text { estudo, bem como a equipe que elaborou o referido } \\
\text { Relatório Consolidado }\end{array}$ \\
\hline CAPÍTULO 2 & LEGISLAÇÃO AMBIENTAL & $\begin{array}{l}\text { Apresenta a legislação brasileira que se refere à Política } \\
\text { de Meio Ambiente nos âmbitos federal, estadual e } \\
\text { municipal, bem como no que diz respeito à } \\
\text { regulamentação do Banco Mundial de relevância para } \\
\text { o projeto }\end{array}$ \\
\hline CAPÍTULO 3: & DESCRIÇÃO DO PROJETO. & $\begin{array}{l}\text { Justificativas, objetivos e a descrição do } \\
\text { empreendimento, destacando as fases de implantação, } \\
\text { operação e desativação do Empreendimento }\end{array}$ \\
\hline CAPÍTULO 4: & CONDIÇÕES AMBIENTAIS & $\begin{array}{l}\text { Justificativas da área estudada e seus limites e } \\
\text { condições dos Meios Físico e Biótico, tendo como } \\
\text { referência a área de influência do Gasoduto e as } \\
\text { análises de sensibilidade ambiental }\end{array}$ \\
\hline CAPÍTULO 5: & MEIO SÓCIO-ECONÔMICO & $\begin{array}{l}\text { Apresentam-se as variáveis socioeconômicas com } \\
\text { probabilidade de serem afetadas, em sua área de } \\
\text { influência, a partir de informações básicas que visaram } \\
\text { identificar, interpretar e avaliar os impactos do projeto } \\
\text { sobre o Meio Socioeconômico }\end{array}$ \\
\hline CAPÍTULO 6: & IMPACTOS AMBIENTAIS. & $\begin{array}{l}\text { Avaliação dos impactos causados quando da } \\
\text { implantação do projeto, bem como propostas de } \\
\text { programas a serem desenvolvidos para mitigar os } \\
\text { impactos ambientais }\end{array}$ \\
\hline CAPÍTULO 7: & PLANOS E PROGRAMAS AMBIENTAIS & $\begin{array}{l}\text { Estabelecimento de diretrizes e padrões para minimizar } \\
\text { e mitigar potenciais impactos da construção e } \\
\text { operação do Empreendimento sobre os Meios Físico, } \\
\text { Biológico e Econômico }\end{array}$ \\
\hline CAPÍTULO 8: & PROGRAMA DE CONSULTA À POPULAÇÃO. & $\begin{array}{l}\text { Relato cronológico das ações e contatos com Órgãos } \\
\text { Públicos, Organizações Não Governamentais (ONGs), } \\
\text { comunidade científica, associações e demais } \\
\text { representantes da sociedade civil organizada. }\end{array}$ \\
\hline CAPÍTULO 9: & CONCLUSÕES E RECOMENDAÇÕES. & $\begin{array}{l}\text { Apresentação das conclusões e as recomendações } \\
\text { associadas à construção e operação do Gasoduto }\end{array}$ \\
\hline CAPÍTULO 10: & BIBLIOGRAFIA. & $\begin{array}{l}\text { Referências bibliográficas e principais fontes } \\
\text { consultadas. }\end{array}$ \\
\hline
\end{tabular}




\subsection{Programas Ambientais do PBA do Gasoduto Bolívia Brasil}

A aplicação da AIA - Avaliação dos Impactos Ambientais, conforme preconizado pelas Resoluções CONAMA 01 e 237, descritas anteriormente no item 2.2.1 dessa monografia, identificou e caracterizou numa Matriz de Impactos, 25 impactos. A partir dessa Matriz, as ações de mitigação dos impactos identificados foram organizadas em 15 Programas Ambientais visando evitar, minimizar, controlar ou mitigar os impactos identificados do Empreendimento Gasoduto Bolívia Brasil, para as fases de implantação, construção e operação, aplicáveis aos Meios Físico, Biótico e Socioeconômico. Esses programas foram detalhados e apresentados no Projeto Básico Ambiental (PBA), definido em Termo de Referência emitido pelo IBAMA.

Em termos de estrutura de Gestão Ambiental para as obras de implantação das obras do Gasoduto Bolívia Brasil, a PETROBRAS definiu uma equipe formada por um Assessor de Meio Ambiente, além de técnicos de segurança e meio ambiente para garantir a implantação dos Programas Ambientais de forma adequada e cumprindo todos os requisitos ambientais nas obras, definidos nos Estudos de Impacto Ambiental (EIA). Havia um sistema de auditoria ambiental para garantir que as contratadas para execução das obras, responsáveis pela coordenação das atividades de preservação e proteção ambiental nas frentes de trabalho, executassem as ações definidas nos Programas Ambientais (PETROBRAS, 1997).

Foram previstos e implementados 10 programas visando a proteção ao meio ambiente, todos vinculados diretamente às obras (PETROBRAS, 1997), conforme lista apresentada a seguir: 
Tabela14: Programas Ambientais para as Obras

\begin{tabular}{|c|c|}
\hline \multicolumn{2}{|c|}{ Programas de Proteção ao Meio Ambiente Vinculados Diretamente às Obras } \\
\hline Programas & Breve descrição \\
\hline $\begin{array}{l}\text { - Estabilidade de encostas e } \\
\text { controle de processos erosivos }\end{array}$ & $\begin{array}{l}\text { mitigar erosões, transporte de sedimentos e instabilidade de encostas, } \\
\text { executando-se obras de proteção passivas para evitar assoreamento } \\
\text { dos rios e instabilidade da faixa de servidão }\end{array}$ \\
\hline - Saúde da mão -de-obra & $\begin{array}{l}\text { acompanhar a saúde dos trabalhadores, garantir-Ihes um rápido } \\
\text { atendimento em caso de acidentes e desenvolver ações voltadas ao } \\
\text { controle de doenças sexualmente transmissíveis }\end{array}$ \\
\hline $\begin{array}{l}\text { - Gerenciamento de riscos e } \\
\text { perigos }\end{array}$ & $\begin{array}{l}\text { diminuir os riscos e perigos identificados na Análise Preliminar de } \\
\text { Perigo e implantar o Plano de Contingência. }\end{array}$ \\
\hline $\begin{array}{l}\text { - Plano para gerência e controle } \\
\text { de impactos ambientais }\end{array}$ & $\begin{array}{l}\text { Criação pela contratadas de programas para adequar e monitorar os } \\
\text { métodos construtivos, de forma a mitigar os impactos ambientais } \\
\text { previstos. }\end{array}$ \\
\hline $\begin{array}{l}\text { - Monitoramento e consultoria } \\
\text { ambiental }\end{array}$ & $\begin{array}{l}\text { detalhar os Programas Ambientais e garantir o atendimento das } \\
\text { diretrizes, planos e programas ambientais }\end{array}$ \\
\hline - Investigação minerária & $\begin{array}{l}\text { atualizar as informações relacionadas às áreas com potencial mineral, } \\
\text { minimizando os potenciais impactos a serem gerados }\end{array}$ \\
\hline $\begin{array}{l}\text { - Avaliação e salvamento do } \\
\text { patrimônio arqueológico }\end{array}$ & $\begin{array}{l}\text { diagnosticar a presença de sítios arqueológicos de alta visibilidade e } \\
\text { baixa visibilidade nas áreas atravessadas pelo Gasoduto }\end{array}$ \\
\hline - Apoio técnico às prefeituras & $\begin{array}{l}\text { buscar integração entre Empreendedor, suas contratadas e Prefeituras } \\
\text { Municipais que sofrerão interferências diretas e indiretas em sua infra- } \\
\text { estrutura de serviços e equipamentos, decorrente das obras }\end{array}$ \\
\hline - Comunicação social & $\begin{array}{l}\text { fornecer informações sobre as etapas e ações do Empreendimento } \\
\text { (implantação e operação), estabeler ligação permanente entre o } \\
\text { empreendedor e as comunidades afetadas. }\end{array}$ \\
\hline $\begin{array}{l}\text { - Revegetação de áreas } \\
\text { impactadas durante as obras }\end{array}$ & $\begin{array}{l}\text { restabelecer a cobertura vegetal das áreas atingidas, para evitar os } \\
\text { processos erosivos, promovendo essa revegetação com espécies } \\
\text { nativas típicas da região, aptas a atraírem a fauna local }\end{array}$ \\
\hline
\end{tabular}

Fonte: PETROBRAS (1997) 
Também foram previstos e implementados 05 programas visando a compensação social e ambiental (PETROBRAS, 1997), conforme lista apresentada a seguir:

Tabela 15: Programas ambientais Compensatórios

\begin{tabular}{|c|c|}
\hline \multicolumn{2}{|r|}{ Programas Ambientais Compensatórios } \\
\hline Programas & Breve descrição \\
\hline - Apoio à comunidade & $\begin{array}{l}\text { fornecer apoio material, técnico e financeiro às comunidades direta e } \\
\text { indiretamente influenciadas, visando minimizar impactos ambientais no Meio } \\
\text { Sócio-Econômico, garantindo a manutenção e melhoria da qualidade de vida }\end{array}$ \\
\hline $\begin{array}{l}\text { - Educação ambiental e } \\
\text { sanitária }\end{array}$ & $\begin{array}{l}\text { instruir as comunidades e instituições sobre problemas ambientais locais, } \\
\text { formado conceitos e adquirindo competências visando a preservação e } \\
\text { melhoria ambiental local, com vistas a permitir uma convivência harmônica } \\
\text { entre o Homem e a Natureza. }\end{array}$ \\
\hline $\begin{array}{l}\text { - Recuperação de á reas já } \\
\text { degradadas }\end{array}$ & $\begin{array}{l}\text { estimular o associativismo e a participação das comunidades locais nos } \\
\text { processos de recuperação da floresta nativa e quanto ao uso de culturas } \\
\text { sustentáveis comercialmente, em áreas revegetadas, adequando sua } \\
\text { exploração a práticas de conservação do solo, da água e da cobertura vegetal }\end{array}$ \\
\hline $\begin{array}{l}\text { - Apoio a áreas legalmente } \\
\text { protegidas }\end{array}$ & $\begin{array}{l}\text { delimitação cartográfica de Áreas Protegidas, incluíndo seu fortalecimento } \\
\text { institucional e consolidação fundiária. }\end{array}$ \\
\hline $\begin{array}{l}\text { - Apoio a áreas } \\
\text { ecologicamente sensíveis }\end{array}$ & $\begin{array}{l}\text { conservar e proteger os recursos florísticos e faunísticos, constituintes da } \\
\text { biodiversidade abrigada pela reserva da biosfera da Mata Atlântica, } \\
\text { severamente impactada, ao longo dos anos, pelas ações antrópicas. }\end{array}$ \\
\hline
\end{tabular}

Fonte: PETROBRAS (1997)

Durante o processo de licenciamento, notadamente no período de execução das obras, empresas contratadas para fiscalização ambiental encaminharam relatórios de atendimento às condicionantes das L.P. e L.I., incluindo o atendimento aos programas definidos no PBA (PETROBRAS, 1997).

Próximo ao final das obras foram realizadas diversas vistorias pelos órgãos ambientais visando verificar, in loco, o referido atendimento. Assim, em 1999 foi liberado para operação o Trecho Norte do Gasoduto Bolívia Brasil e em Março de 2000, aconteceu a liberação total da operação, a partir da emissão da LO 081/2000 (PETROBRAS, 1997).

\subsection{Atendimento às Condicionantes da L.O. 081/2000 - original}

O atendimento às condicionantes da LO 081/2000, emitida em março de 2000, foi realizado imediatamente a partir de sua emissão. 
Basicamente a L.O. contém condicionantes gerais, relacionadas à publicação da obtenção da própria LO; condições de cancelamento da licença; responsabilidade de acidentes e revogação de licenças anteriores.

Já as condicionantes específicas trazem, em sua maioria, a obrigação de atendimento às situações não concluídas durante as obras e apenas três relacionadas ao envio sistemático de informações ao órgão ambiental, todas relacionadas a: (i) manutenção da faixa (condicionante 2.4), (ii) inspeção e manutenção das instalações fixas (condicionantes 2.10) e (iii) relatórios sobre expansão urbana ao longo da faixa de servidão (condicionante 2.11)

De acordo com as informações do Parece Técnico do IBAMA (02001.002821/2014-18 COEND/IBAMA), durante a operação do Gasoduto, até a data da renovação da L.O., foram produzidos e encaminhados ao IBAMA 21 relatórios de atendimento às condicionantes dessa licença.

Conforme verificado no Parecer 002821/2014, de 2014 até a renovação propriamente da L.O., em 2014, o processo foi intensificado pelo IBAMA, com algumas ações específicas, como reuniões técnicas; realização de vistoria aérea e terrestre; atendimento aos comentários do IBAMA referentes às vistorias e Estudos de Análise de Riscos encaminhados pela TBG.

O mesmo parecer analisa cada condicionante da LO 081/2000, emitida em março de 2000, destacando o atendimento ou não das mesmas, apresenta o atendimento, pela TBG, dos ofícios emitidos pelo IBAMA (considerando questionamentos referentes aos meios socioeconômico, biótico e físico). Por fim, tal parecer presenta a conclusão das avaliações e propõe a minuta da LO 081/2000 Renovada.

Depois de seguidos os trâmites administrativos pela TBG e realizado o pagamento específico, o IBAMA emitiu, em julho de 2014 a LO 081/2000 Renovada.

\subsection{Atendimento das Condicionantes da LO 081/2000 - Renovada}

A LO 081/2000 Renovada, com prazo de 10 anos, foi emitida em 14 de julho de 2014, considerando 18 condicionantes específicas, apresentadas a seguir de forma sucinta (IBAMA, 2014): 
Tabela16: Condicionantes da LO 081/2000, Renovada - 2014

\begin{tabular}{ll}
$\mathbf{N}^{\mathbf{0}}$ & \multicolumn{1}{c}{ CONDICIONANTES ESPECÍFICAS } \\
\hline 2.1 & Elaboração do PBA \\
2.2 & Relatório Anual de Execução dos Programas Ambientais \\
2.3 & Vedada a exposição do duto / Comunicar ao IBAMA \\
2.4 & Atender NT 32 / ANP 215 - Intervenções na faixa: Relatório Anual \\
2.5 & Comunicar obras emergenciais: Eventuais \\
2.6 & Revisar EAR \\
2.7 & Reunião com Prefeituras (divulgar resultados do EAR) \\
2.8 & Revisar PGR / PAE \\
2.9 & Apresentar cronograma de simulados / treinamentos \\
2.10 & Concluir compensação Ambiental - Estado de SP \\
2.11 & Concluir atividades de Reposição Florestal - Estado do RS \\
2.12 & Apresentar Análise Gás: Relatório Anual \\
2.13 & Informar início de operação de novos empreendimentos: Eventual \\
2.14 & Apresentar o Projeto Recuperação Cinturões Verdes ECOMP \\
2.15 & Finalizar as padronizações dos Shelters para armazenamento de resíduos \\
2.16 & Informar mudanças de Classe Locação: Relatório Anual \\
2.17 & Realizar bianualmente Auditoria Ambiental \\
2.18 & Definição da revogação das LO anteriores
\end{tabular}

Fonte: IBAMA (2014)

Numa análise simplificada, em termos de atendimentos, verificou-se:

- Atendimento até 180 dias a partir da emissão da L.O., para quatro condicionantes: $2.1,2.9,2.14$ e 2.15 ;

- Prazos específicos definidos, mas não associados diretamente à data da emissão da L.O., para três condicionantes: 2.6, 2.7 e 2.8;

- Atendimento em um ano a partir da emissão da L.O., para duas condicionantes: 2.2 e 2.12 ;

- Atendimento pontual a partir do ocorrido gerando obrigações para a TBG, para cinco condicionantes: 2.3, 2.4, 2.5, 2.13 e 2.16;

- Atendimento em dois anos a partir da emissão da L.O., para uma Condicionante: 2.17;

- Atendimento contínuo até sua conclusão sem prazo definido, para duas condicionantes: 2.10 e 2.11;

- Não Gerou obrigações para TBG, para uma condicionante: 2.13.

Vale destacar que o propósito desse estudo é verificar a sistematização da gestão ambiental da operação de um Gasoduto, a partir de adoção de Plano Básico Ambiental para operação considerando, nesse sentido, a elaboração do 
PBA (Condicionante 2.1 da LO 081/2000 Renovada), incluindo a condicionante 2.14 (Projeto de Recuperação Cinturões Verde das Estações de Compressão), por ter havido o entendimento da TBG que tal Projeto, pelas suas características de recuperação e preservação ambiental, fazia parte do PBA.

\subsection{O PBA do Gasoduto Bolívia Brasil}

A renovação da LO 081/200, em 2014, trouxe em seu corpo novas condicionantes, com destaque para a condicionante 2.1, que determinou a elaboração de um Plano Básico Ambiental (PBA) para operação do Gasoduto (IBAMA, 2014).

Vale destacar que o referido PBA foi proposto de forma inédita pelo órgão ambiental, sendo composto por programas ambientais específicos para minimizar possíveis impactos ambientais relacionados à operação do Gasoduto Bolívia Brasil, conforme apresentado a seguir (SARNO et al, 2017):

1. Programa Ambiental para a Construção - PAC;

2. Programa de Monitoramento e Controle da Poluição Atmosférica;

3. Programa de Monitoramento e Controle de Ruído;

4. Programa de Gerenciamento de Resíduos e Efluentes;

5. Programa de Monitoramento e Controle de Erosões;

6. Programa de Manutenção de Faixa e Relação com Terceiros;

7. Programa de Educação Ambiental;

8. Programa de Comunicação Ambiental;

9. Programa de Recuperação dos Cinturões Verdes das ECOMP;

10. Programa de Gerenciamento de Riscos.

\subsubsection{Matriz de Impacto}

A primeira ação envolvendo a elaboração do PBA foi elaborar uma nova Matriz de Impactos Ambientais, totalmente voltada para a operação do gasoduto. O desenvolvimento dessa Matriz considerou o levantamento dos principais aspectos da operação do gasoduto os quais poderiam ocasionar impactos ao meio ambiente, tendo sido adotada metodologia específica, com uso de Matriz de Leopold, simplificada (Biodinâmica, 2014)

No processo de avaliação, a empresa que elaborou o PBA inicialmente considerou os impactos previstos no EIA original, totalizando 26 impactos, conforme figura 13 apresentada a seguir: 
Figura11: Impactos identificados no EIA original
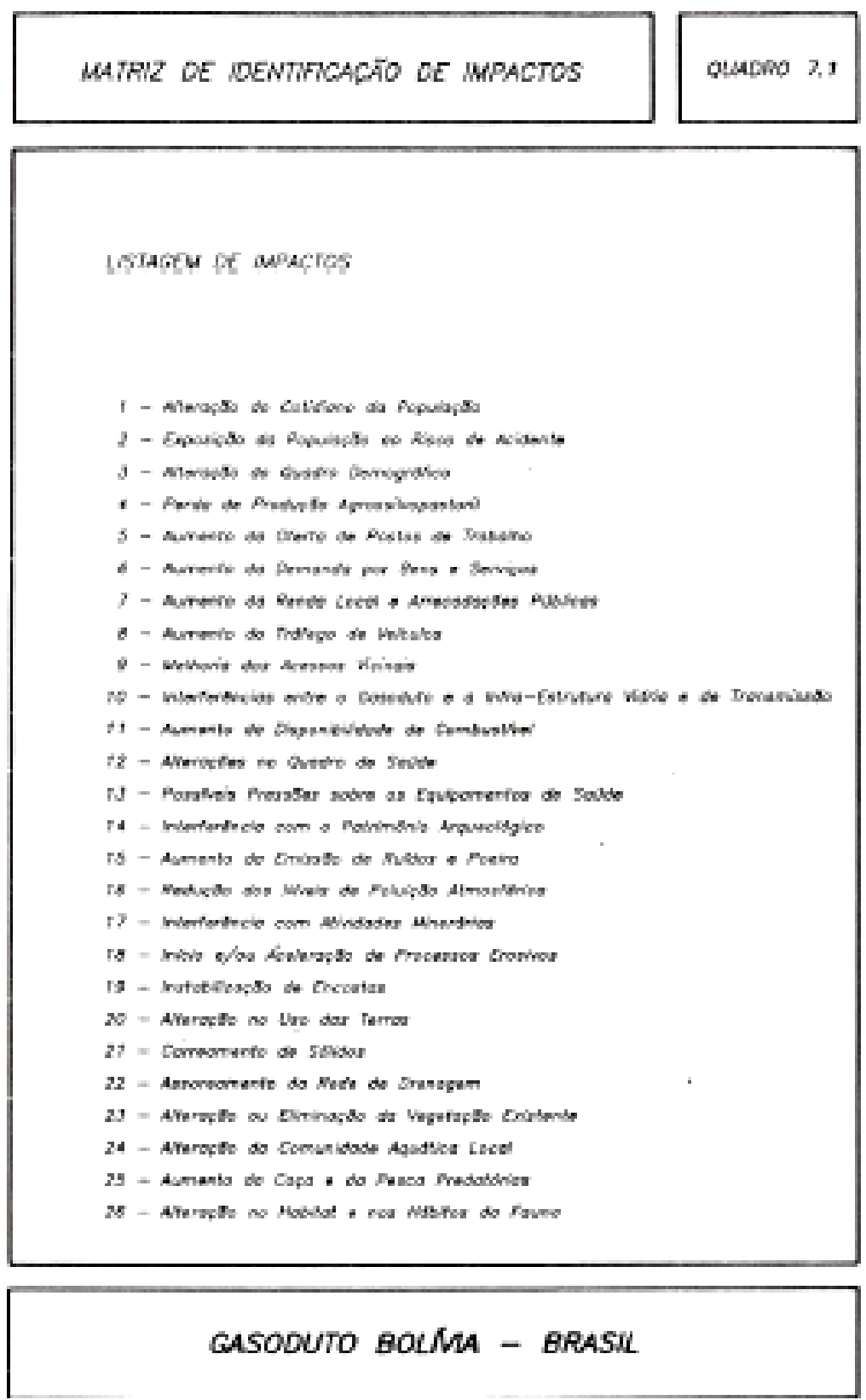

Fonte: Biodinâmica, 2014

O processo de proposição da nova Matriz de Impactos, específica para operação, segundo a Biodinâmica (2014), considerou alguns impactos previstos na Matriz de Impacto do EIA, relativos à operação do Gasoduto (impactos 15, 16 18, 19, 20, 23 e 26), tendo o enunciado do impacto 16 mudado para Alteração dos níveis de Ruídos e da Poluição Atmosférica, e o mesmo agregado ao impacto 15. Além disso, após as análises realizadas, mais dois novos impactos 
foram identificados, analisados e propostos, totalizando assim 09 impactos ambientais na nova Matriz de Impacto, conforme tabela 17 apresentada a seguir:

Tabela17: Nova relação de Impactos ambientais - 2014

\begin{tabular}{c||l} 
N $^{\mathbf{2}}$ & \multicolumn{1}{|c}{ Impacto Ambiental na fase de operação do Gasoduto } \\
\hline \hline 1 & Melhoria dos Acessos Vicinais (impacto 9 do EIA) \\
\hline 2 & Alteração no Uso das Terras (impacto 20 do EIA) \\
\hline 3 & Usos Indevidos da Faixa de Servidão por Terceiros (novo) \\
\hline 4 & Interferências na Sinalização do Gasoduto (novo) \\
\hline 5 & Alteração dos Níveis de Ruídos e de Poluição Atmosférica (adaptação dos impactos 15 e 16 do EIA) \\
\hline 6 & Início e/ou Aceleração de Processos Erosivos (impacto 18 do EIA) \\
\hline 7 & Estabilização de Encostas (impacto 19 do EIA) \\
\hline 9 & Alteração ou Eliminação da Vegetação Existente (impacto 23 do EIA) \\
\hline
\end{tabular}

Fonte: Biodinâmica, 2014

Posteriormente a seleção e identificação dos impactos, foi realizada a reavaliação dos mesmos, considerando na análise a definição da magnitude e importância de cada um deles a partir de atributos previamente definidos (Biodinâmica, 2015), conforme apresentado na Matriz de Avaliação de Impacto Ambiental apresenta a seguir:

Figura 12: : Nova Matriz de Impacto Ambiental - 2014

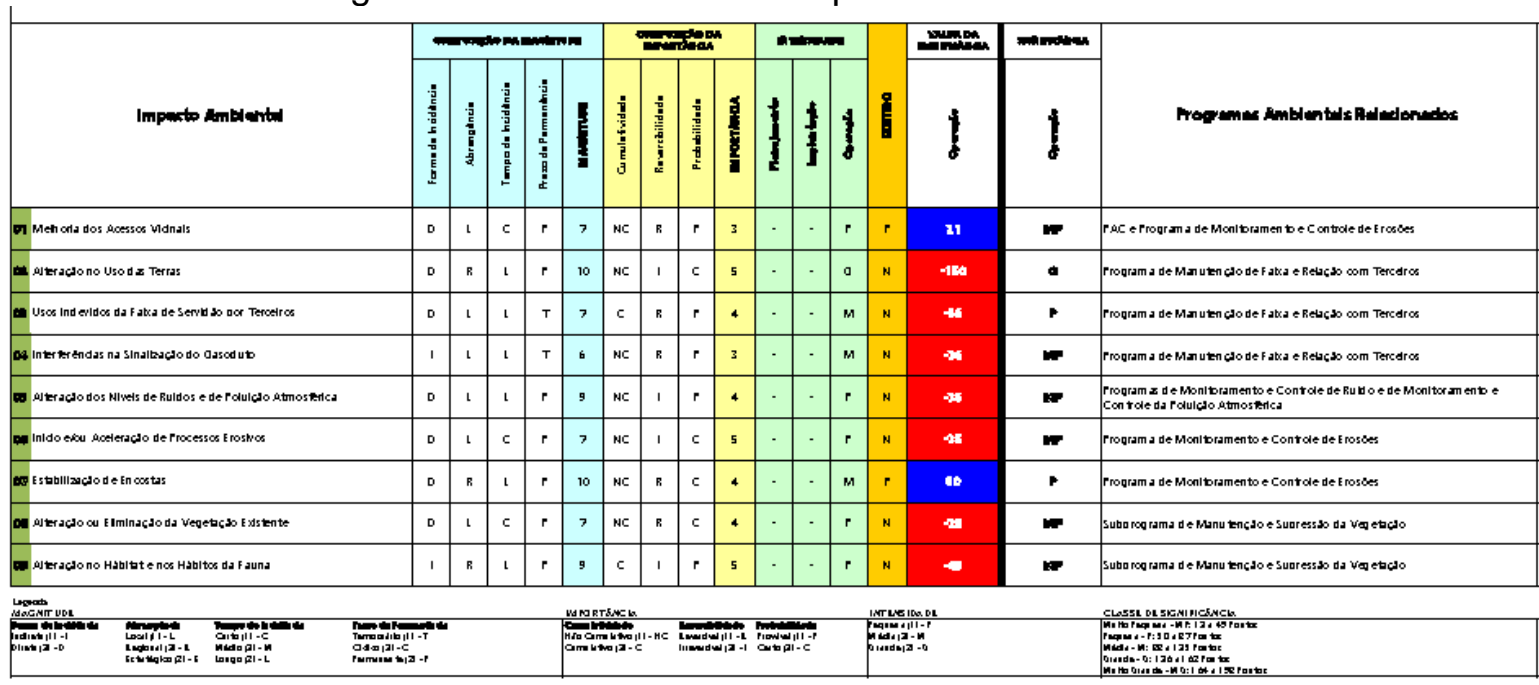

Fonte: Biodinâmica, 2014

\subsubsection{Elaboração do PBA}

Visando atendimento ao que determinou a LO 081/2000 Renovada na Condicionante 2.1, definindo a elaboração do PBA em 180 dias após a data da emissão da referida L.O., a Diretoria da TBG, após analisar a situação, determinou a mobilização de técnicos de onze gerencias da companhia (SMS, 
Jurídica, Estratégia e Desempenho, Operação, Planejamento, Manutenção de dutos, Manutenção de instalações, Engenharia, Compras, TI e Comunicação), sendo todos coordenados pela área de Meio Ambiente e apoiados por empresa contratada, especializada em estudos ambientais. Assim, para elaboração e formatação dos Programas Ambientais definidos na LO 081/2000 Renovada, no prazo previsto, foi feito planejamento prévio, resultando no cronograma abaixo (SARNO et. al., 2017):

Figura 13: Cronograma de atividades para elaborar o PBA

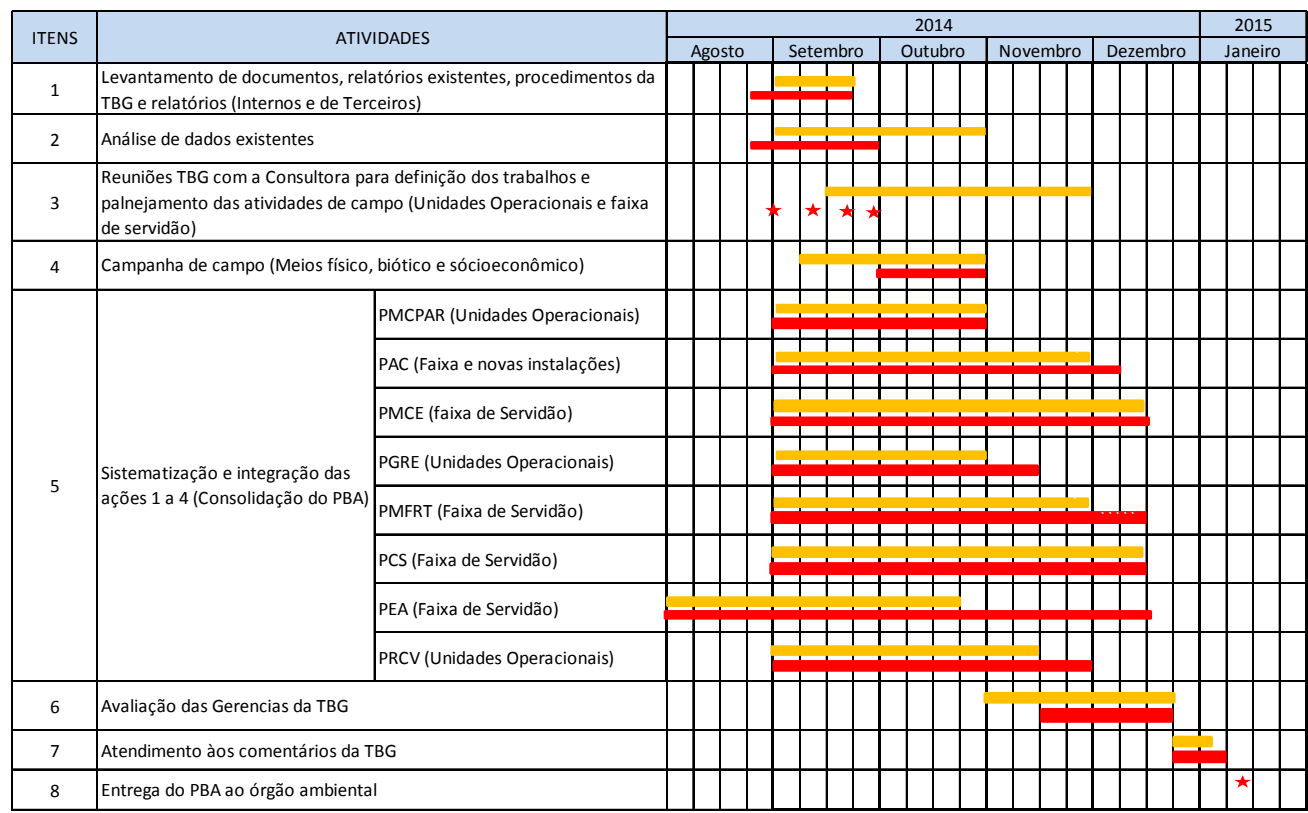

Fonte: Sarno et al. - 2017

Conforme Sarno et. al. (2017), as ações planejadas para elaboração do PBA no prazo estabelecido pela LO 081/2000 Renovada, consideraram coleta e análise de documentos referentes a 15 anos de operação do Gasoduto Bolívia Brasil. Assim, realizou-se

- Consultas e análises a 223 documentos (memoriais descritivos, relatórios, padrões, procedimentos, planilhas, desenhos, materiais informativo, dentre outros);

- Consultas e análises a 735 mapas de risco geotécnico e 104 imagens de satélite;

- Realização de visita técnica, pela empresa contratada, a trechos específicos da faixa de servidão do gasoduto, Pontos de Entrega e Estações de Compressão da TBG;

- Realização de 12 reuniões com a empresa contratada. 
- Contatos sistemáticos com técnicos do órgão ambiental para esclarecimentos;

- Realização de 07 reuniões com as gerências envolvidas;

- Realização de avaliações críticas e comentários pelas gerências da TBG, nos dois últimos meses, visando à consolidação e aprovação interna, antes da apresentação ao IBAMA.

De acordo Sarno et. al.. (2017), os resultados foram positivos e o trabalho ocorreu conforme previsto e na qualidade esperada, tendo sido seguido rigorosamente tal planejamento, conforme demonstrado na Figura 16, a seguir apresentada:

Figura 14: Acompanhamento das atividades de realização do PBA

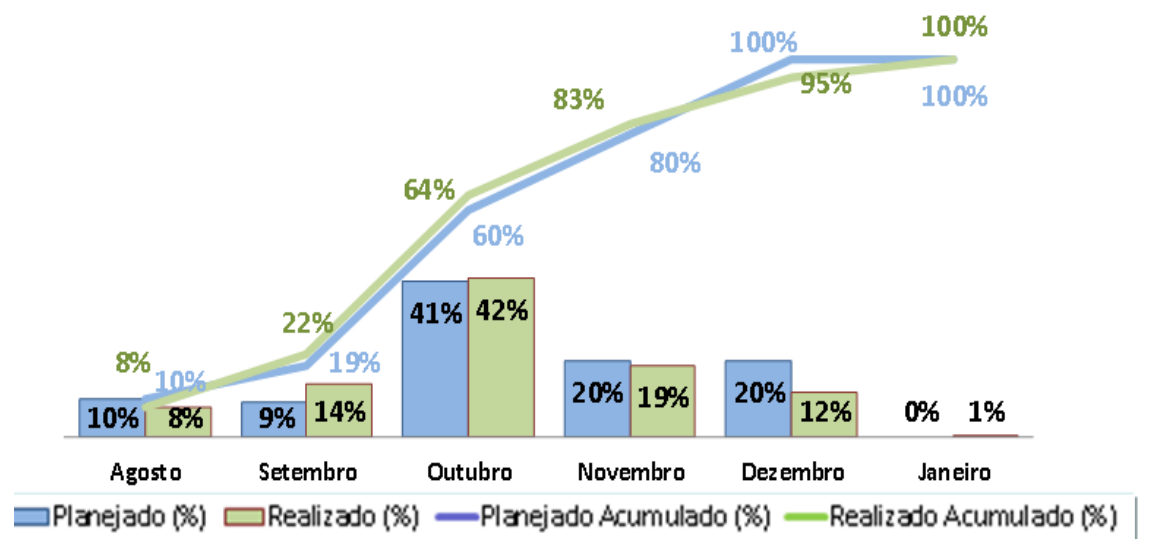

Fonte: Sarno et. al. - 2017 


\section{Resultados e conclusão}

$\mathrm{O}$ atendimento aos questionamentos e, principalmente o atendimento aos órgãos ambientais, é visto pelas empresas como um trabalho adicional, que muitas vezes não agrega valor ao processo de negócios (Sarno, 1995).

No caso em questão, a TBG, dona do Gasoduto Bolívia Brasil, foi criada numa cultura onde a garantia da qualidade, atendimento a requisitos de segurança, meio ambiente e saúde são pilares importantes no seu processo de negócios, que é o transporte de gás natural utilizando o modal de transporte dutoviário (TBG, 2018). Para a elaboração do PBA para operação do Gasoduto Bolívia Brasil foi necessário o apoio das principais gerências da TBG, todos respaldados pela Diretoria da Companhia nas suas decisões, considerando cada etapa de elaboração do PBA.

Ressalta-se também a disponibilidade dos técnicos da companhia na resolução de problemas e na transposição de obstáculos, a exemplo da compatibilização das agendas de todos visando atendimento ao prazo estipulado pelo órgão ambiental para elaboração e entrega do PBA.

Outro obstáculo relevante foi a identificação de documentos necessários para subsidiar a elaboração dos trabalhos. Essa etapa foi acompanhada de perto pela empresa contratada para rever a Avaliação de Impactos e consolidar os Programas do PBA. Foram levantados dados de 15 anos de operação do Gasoduto Bolívia Brasil, armazenados em diferentes bancos de dados da TBG (Sarno et. al., 2017).

Dessa forma, segundo SARNO et. al. (2017), grupos heterogêneos de trabalho foram formados visando à elaboração de cada programa, agrupados de acordo com temas afins, com o objetivo de reunir as informações dispersas nos procedimentos operacionais e definir diretrizes, indicadores e metas para cada assunto de interesse ambiental solicitado pelo órgão ambiental. Todo o trabalho sob a coordenação da gerência de SMS da TBG.

Realizada análise crítica dos dados e elaborados os Programa, constatouse, na prática, que a gestão ambiental da TBG estava totalmente aderente ao solicitado pelo Órgão Ambiental, necessitando apenas de alguns ajustes para 
agrupamento das práticas da companhia na forma de programas ambientais (Sarno et. al. 2017).

Destaca-se que, segundo SARNO et. al. (2017), o objetivo comum da companhia, no caso a elaboração do PBA, resultou em um maior entendimento do licenciamento ambiental por toda força de trabalho, principalmente daqueles que participaram do processo (direta e indiretamente) de elaboração do PBA, bem como tal processo contribuiu para a ampliação da consciência todos em relação às questões ambientais que permeiam os diversas atividades da TBG. Tal entendimento e conscientização reforçaram ainda mais a cultura empresarial da companhia, resultando em um forte comprometimento para o atendimento ao planejamento ressaltando, sobremaneira, o comprometimento da alta direção da TBG no apoio ao atendimento às demandas do órgão ambiental, sendo tal fato um dos pontos altos do projeto.

Quanto aos resultados alcançados na elaboração do PBA para a operação do Gasoduto Bolívia Brasil (Sarno et. al., 2017), pode-se destacar:

1. A sistematização de medidas mitigadoras, na forma de Programas, contribuindo para otimização da gestão ambiental da TBG, antes realizada a partir de procedimentos operacionais de diversas áreas da companhia;

2. A reavaliação da Matriz de Impactos, agora considerando efetivamente os impactos da operação e não mais aqueles projetados durante a realização do Estudo de Impactos Ambientais (EIA), elaborado em 2000;

3. A melhoria do monitoramento ambiental através de indicadores e metas, facilitando o acompanhamento pelos técnicos da TBG, técnicos do órgão ambiental e demais partes interessadas;

4. Maior dispersão da cultura ambiental por toda a companhia;

5. Pleno atendimento às condicionantes da L.O. $n^{\circ}$ 081/2000 Renovada, dentro do prazo estipulado na mesma, incluindo a entregada ao órgão ambiental dos programas ambientais solicitados, na forma de PBA.

Por fim, pode-se concluir, a partir de Sarno et. al. (2017), que a exigência do órgão ambiental licenciador da TBG, no caso o IBAMA, através de condicionante da Licença de Operação 081/2000 renovada, notadamente a solicitação da elaboração do Plano Básico Ambiental (PBA) da operação da TBG, foi de grande importância para evolução e sistematização da gestão ambiental praticada na companhia. Os programas ambientais propostos pelo órgão ambiental, quando implementados, deverão apresentar resultados reais e significativos do processo de Gestão Ambiental, para a própria TBG, o órgão ambiental licenciador e para demais partes interessadas. 


\section{Bibliografia}

ANP - Agência Nacional de Petróleo. Anuário Estatístico Brasileiro do Petróleo, Gás Natural e Biocombustíveis: 2017. Rio de Janeiro: ANP, 2017. Disponível em: <http:www.anp.gov.br>. Acesso em: 26 jan. 2018.

BIODINÂMICA - Engenharia e Meio Ambiente / TBG. Projeto Básico Ambiental PBA de Operação do Gasoduto Bolívia Brasil, Anexo III, Rio de Janeiro, dezembro de 2014. 20 p.

BRASIL Lei Federal 6.938, de 31 de agosto de 1981. Dispõe sobre a Política Nacional do Meio Ambiente, seus fins e mecanismos de formulação e aplicação, e dá outras providências., Brasília, DF, ago. 1981.

BRASIL. Constituição Federal de 1988. Promulgada em 5 de outubro de 1988. Disponível em http://www.planalto.gov.br/ccivil_03/Constituicao/Constituicao.htm.

BRASIL. Decreto n. 9.9274, de 06 de junho de 1990. Regulamenta a Lei $\mathrm{n}^{0}$ 6.902, de 27 de abril de 1981, e a Lei $n^{\circ}$ 6.938, de 31 de agosto de 1981, que dispõem, respectivamente sobre a criação de Estações Ecológicas e Áreas de Proteção Ambiental e sobre a Política Nacional do Meio Ambiente, e dá outras providências. Brasília, DF, jun. 1990.

BRASIL. Lei n. 11.909, de 04 de março de 2009. Dispõe sobre as atividades relativas ao transporte de gás natural, de que trata o art. 177 da Constituição Federal, bem como sobre as atividades de tratamento, processamento, estocagem, liquefação, regaseificação e comercialização de gás natural; altera a Lei no 9.478, de 6 de agosto de 1997; e dá outras providências, Brasília, DF, mar. 2009.

BRASIL. Lei n. 2.004, de 03 de outubro de 1953. Dispõe sobre a Política Nacional do Petróleo e define as atribuições do Conselho Nacional do Petróleo, institui a Sociedade Anônima, e dá outras providências., Brasília, DF, out. 1953.

BRASIL. Lei n. 7.735, de 22 de fevereiro de 1989. Dispõe sobre a extinção de órgão e de entidade autárquica, cria o Instituto Brasileiro do Meio Ambiente e dos Recursos Naturais Renováveis e dá outras providências, Brasília, DF, fev. 1989.

BRASIL. Lei n. 9.478, de 06 de agosto de 1997. Dispõe sobre a política energética nacional, as atividades relativas ao monopólio do petróleo, institui o Conselho Nacional de Política Energética e a Agência Nacional do Petróleo e dá outras providências, Brasília, DF, ago. 1997.

BRASIL. Lei No 6.803, de 2 de julho de 1980. Dispõe sobre as diretrizes básicas para o zoneamento industrial nas áreas críticas de poluição, e dá outras providências, Brasília, DF, jul. 1980. 
BRASIL. Resolução CONAMA n. 01, de 17 de fevereiro de 1986. Dispõe sobre critérios básicos e diretrizes gerais para a avaliação de impacto ambiental, Brasília, DF, fev. 1986.

BRASIL. Resolução CONAMA n. 06, de 22 de outubro de 1987. Dispõe sobre o licenciamento ambiental de obras do setor de geração de energia elétrica, Brasília, DF, out. 1987.

BRASIL. Resolução CONAMA n. 237, de 19 de dezembro de 1997. Dispõe sobre a revisão e complementação dos procedimentos e critérios utilizados para o licenciamento ambiental, Brasília, DF, dez. 1997.

BRUNDTLAND, Gro Harlem. Comissão Mundial Sobre Meio Ambiente e Desenvolvimento. O nosso futuro comum. 2. ed. Rio de Janeiro: FGV, 1991. Our commom future, 1987.

CALDAS, Flaviana Venturim. Estudos de impacto ambiental em empreendimentos dutoviários: análise da elaboração, acompanhamento e monitoramento durante a fase de construção. 2006. 178 f. Dissertação (Mestrado) - Curso de Sistemas de Gestão, Laboratório de Tecnologia e Gestão de Negócios e Meio Ambiente - LATEC, Universidade Federal Fluminense, Niterói / RJ, 2006.

CARMO, Aline B. C. e Silva, Alessandro S. S. Licenciamento ambiental federal no Brasil: perspectiva histórica, poder e tomada de decisão em um campo em tensão , CONFINS [Online], 19 | 2013, posto online no dia 16 Novembro 2013, consultado o 05 Abril 2018. URL: http://journals.openedition.org/confins/8555; DOI : $10.4000 /$ confins. 8555

CORTELETTI, Rosyelle Cristina. Desenvolvimento de metodologia para concepção de traçados de dutos de transporte de gás natural. 2009. $174 \mathrm{f}$. Dissertação (Mestrado) - Curso de Programa de Pós-graduação em Geotecnia, Universidade Federal de Ouro Preto, Ouro Preto / MG, 2009.

EPA - United States Environmental Protection Agency. A citizen's guide to the National Environmental Policy Act: having your voice heard. 2007. 55 p. Disponível em: <www.ceq.doe.gov>. Acesso em: 25 nov. 2017.

EPL - Empresa de Planejamento e Logística. Anuário Estatístico de Transportes 2010-2016. Brasília: MTPA, 2017. Disponível em: <http://www.transportes.gov.br/images/2017/Sumário_Executivo_AET_-_2010__2016.pdf>. Acesso em: 03 mar. 2018.

FREIRE, José Luiz de França et al. Engenharia de Dutos. Rio de Janeiro: ABCM, 2009.

GODOY, André Vanonni de. A eficácia do Licenciamento Ambiental como instrumento publico de gestão do meio ambiente. Brasília: OAB Editora, 2005.

IBAMA - Instituto Brasileiro do Meio Ambiente e dos Recursos Naturais Renováveis. LO 081/2000: Licença de Operação do Gasoduto Bolívia Brasil Renovada. Brasília: IBAMA, 2014.

IBAMA - Instituto Brasileiro do Meio Ambiente e dos Recursos Naturais Renováveis. Instrução Normativa $n^{\circ}$ 101. Brasília: IBAMA, 2006. 4 p. Disponível 
em: <http://www.mma.gov.br/estruturas/pnf/_arquivos/in ibama101 06.pdf>. Acesso em: 05 maio 2018.

IBAMA COEND CGENE DILIC. Parecer Técnico no 009/2008: Análise do Relatório de Atendimento às Condicionantes exigidas na Licença Prévia $n^{\circ}$ 257/2007 e do Projeto Básico Ambiental do Gasoduto Caraguatatuba - Taubaté. Brasília: Ibama, 2007. 19 p. Disponível em: <https://servicos.ibama.gov.br/licenciamento/consulta_empreendimentos.php>. Acesso em: 02 maio 2018.

IBAMA. Licenciamento de gasodutos. Disponível em: $<$ https://servicos.ibama.gov.br/licenciamento>. Acesso em: mar, abri, e mai.. 2018.

IBAMA COEND. Parecer Técnico no 02001.002821/2014-18 COEND/IBAMA: Análise relativa ao atendimento das condicionantes da LO $n^{\circ} 081 / 2000$. Brasília: Ibama, $2014 . \quad 20 \quad$ p. $\quad$ Disponível em: $<$ https://servicos.ibama.gov.br/licenciamento/consulta_empreendimentos.php $>$. Acesso em: 10 maio 2018.

MARRIOTT, Betty Bowers. Environmental Impact Assessment: a practical guide. United States: Mcgrawhill, 1997. 320 p.

MEADOWS, Donella $\mathrm{H}$. et al (Org.). Limites do crescimento: um relatório para o Clube de Roma sobre o dilema da humanidade. São Paulo: Editora Perspectiva, 1973. $248 \mathrm{p}$.

MMA - IBAMA. Guia de Procedimentos do Licenciamento Ambiental: documento de referência. Brasília: MMA/IBAMA, 2002. Disponível em: <http://www.mma.gov.br/estruturas/sqa_pnla/_arquivos/Procedimentos.pdf>.

Acesso em: 08 mar. 2018.

MMA - SISNAMA. Caderno de Licenciamento Ambiental. Brasília: Ministério de Meio Ambiente, 2009. Programa Nacional de Capacitação de Gestores Ambientais. Disponível em: <http://www.mma.gov.br/estruturas/dai_pnc/_arquivos/pnc_caderno_licenciamen to_ambiental_01_76.pdf>. Acesso em: 25 jan. 2018.

MMA -IBAMA. Guia Prático LAF: orientações sobre o acesso ao Serviço LAF e procedimentos para solicitação de licenciamento. Brasília: MMA - IBAMA, 2018. Disponível em: <http://ibama.gov.br/empreendimentos-e-projetos/licenciamentoambiental-processo-de-licenciamento\#FCA>. Acesso em: 08 mar. 2018.

MMA-IBAMA. Consulta a empreendimentos. 2018. Disponível em: <https://servicos.ibama.gov.br/licenciamento/consulta_empreendimentos.php>. Acesso em: 10 maio 2018

MME - Ministério de Minas e Energia. Boletim mensal de acompanhamento de Gás Natural. 131f. Brasília: MME, 2018. Disponível em: <www.mme.gov.br>. Acesso em: 6 mar. 2018. 
MME; EPE; ANP. Gás para Crescer: relatório técnico. Brasília: MME, 2016. 21 p. Disponível

em: <http://www.mme.gov.br/documents/10584/4033411/0.Gás+para+Crescer_Relat ório+Técnico.pdf/91716743-86ae-44e9-a838-c850a1f5d6cb>. Acesso em: 28 abr. 2018.

MOREIRA, Iara Verocai Dias. Avaliação de Impacto Ambiental - AIA. Rio de Janeiro: Feema / Fundação Estadual de Meio Ambiente, 1989. 41 p.

MOREIRA, Paula Gomes. A conferencia das Nações Unidas sobre Meio Ambiente e Desenvolvimento e seu legado na politica ambiental brasileira. Anais do Seminário Nacional da Pós-graduação em Ciências Sociais, Espirito Santo, v. 1, n. 1, p.1-19, 2011. Disponível em: <http://periodicos.ufes.br/SNPGCS/article/view/1522>. Acesso em: 14 mar. 2018. OLIVEIRA, Carla Maria Frantz. de Vasconcelos. Licenciamento Ambiental. 2012. 132 f. Monografia (Especialização) - Curso de Programa de Pós-graduação em Direito, Universidade Federal do Rio Grande do Sul - UFRGS, Porto Alegre, 2012.

PETROBRAS - Petróleo Brasileiro S.A. / SEGEN / GASBOL. Estudo de Impacto Ambiental para o Trecho Brasileiro do Gasoduto Bolívia Brasil: Relatório Consolidado, Rio de Janeiro, março de 1997. 425 p.

PINTO, Raul Penazzo. Tarifação na malha de Gasodutos de transporte no Brasil: evolução e perspectivas. 2014. 170 f. Dissertação (Mestrado) - Curso de Programa de Pós-graduação em Energia, Universidade de São Paulo, São Paulo, 2014.

POLAR - Inteligência em Meio Ambiente Ltda. / Companhia de Gás do Estado do Rio Grande do Sul. Estudo de Impacto Ambiental (EIA), Volume I. Licenciamento da Rede de distribuição de gás natural Rio Grande do Sul. Porto Alegre: Polar, 2016. 111 p.

SÁNCHES, Luís Enrique. Avaliação de Impacto Ambiental: Conceito e Métodos. 2. ed. São Paulo: Editora Oficina de Textos, 2013. 553 p.

SARNO, Ruy et al. Environment Plan to the Bolivia-Brazil Gas Pipeline Operation. In: Rio Pipeline 2017 Conference \& Exposition - IBP, 24 a 26 de Outubro de 2017, Rio de Janeiro, Technical Papers. Rio de Janeiro: IBP, 2017. $5 \mathrm{p}$.

SARNO, Ruy. Administração Estratégica e Excelência Ambiental: uma visão do desenvolvimento dos negócios considerando o uso racional e a preservação dos recursos naturais. 1995. 102 f. Dissertação (Mestrado) - Curso de Engenharia de Produção, UFRJ/COPPE, Rio de Janeiro, 1995. COPPE/PPE/UFRJ. Rio de Janeiro, 1995.

SOUZA, Alexandre Nascimento. Licenciamento Ambiental no Brasil sob a perspectiva da modernização ecológica. 2009. 226 f. Dissertação (Mestrado) Curso de Programa de Pós-graduação em Ciência Ambiental da USP, Universidade Federal de São Paulo, São Paulo, 2009. 
TBG - TRANSPORTADORA BRASILEIRA GASODYTO BOLIVIA BRASIL S.A. (Org.). Gasoduto Bolívia Brasil. 2018. Disponível em: <http://www.tbg.com.br/pt_br/>. Acesso em: 06 maio 2018.

TOMMASI, Luís Roberto. Estudo de Impacto Ambiental. São Paulo: Cetesb: Terragraph Artes e Informática, 1993. 354 p.

VINCENTINI, Elaine. Plano Básico Ambiental (PBA) como instrumento de Licenciamento Ambiental de ferrovias. 2013. 79 f. Monografia (Especialização) Curso de Pós Graduação Lato Sensu em Curso em Análise Ambiental e Desenvolvimento Sustentável, UNICEUB/CPD, Centro Universitário de Brasília, Brasília, 2013. 